\title{
Structural Characterization of Lignin Isolated from Coconut (Cocos nucifera) Coir Fibers
}

\author{
Jorge Rencoret, ${ }^{* \dagger}{ }^{\dagger}$ John Ralph, ${ }^{\ddagger}$ Gisela Marques, ${ }^{\dagger}$ Ana Gutiérrez, ${ }^{\dagger}$ Ángel T. Martínez, ${ }^{\S}$ \\ and José C. del Río ${ }^{\dagger}$ \\ ${ }^{\dagger}$ Instituto de Recursos Naturales y Agrobiología de Sevilla (IRNAS), CSIC, PO Box 1052, E-41080 Seville, Spain \\ ${ }^{\ddagger}$ Departments of Biochemistry and Biological Systems Engineering, the Wisconsin Energy Institute, and the DOE Great Lakes \\ Bioenergy Research Center, University of Wisconsin, Madison, Wisconsin 53726, United States \\ ${ }^{\S}$ Centro de Investigaciones Biológicas (CIB), CSIC, Ramiro de Maeztu 9, E-28040 Madrid, Spain
}

ABSTRACT: The structure of the isolated milled "wood" lignin from coconut coir has been characterized using different analytical methods, including Py-GC/MS, 2D NMR, DFRC, and thioacidolysis. The analyses demonstrated that it is a $p$ hydroxyphenyl-guaiacyl-syringyl (H-G-S) lignin, with a predominance of $\mathrm{G}$ units (S/G ratio 0.23 ) and considerable amounts of associated $p$-hydroxybenzoates. Two-dimensional NMR indicated that the main substructures present in this lignin include $\beta-$ O-4' alkyl aryl ethers followed by phenylcoumarans and resinols. Two-dimensional NMR spectra also indicated that coir lignin is partially acylated at the $\gamma$-carbon of the side chain with $p$-hydroxybenzoates and acetates. DFRC analysis showed that acetates preferentially acylate the $\gamma-\mathrm{OH}$ in S rather than in G units. Despite coir lignin's being highly enriched in G-units, thioacidolysis indicated that $\beta-\beta^{\prime}$ resinol structures are mostly derived from sinapyl alcohol. Finally, we find evidence that the flavone tricin is incorporated into the coconut coir lignin, as has been recently noted for various grasses.

KEYWORDS: coconut coir, lignin, Py-GC/MS, TMAH, HSQC, DFRC, thioacidolysis, p-hydroxybenzoates, tricin

\section{INTRODUCTION}

Coconut coir fibers are extracted from the tissues surrounding the seed of the coconut palm (Cocos nucifera), a member of the family Arecaceae (palm family). Coir fibers are odorless, lightweight, thick, and strong and have resistance to abrasion. ${ }^{1}$ Industrial products from coconut coir include sacking, brushes, doormats, rugs, mattresses, insulation panels, and packaging. ${ }^{2}$ Coir fibers are mostly composed of cellulose (44\%), hemicelluloses (12\%), lignin (33\%), and extractives (6\%), ${ }^{3}$ which makes this material an interesting feedstock for the production of high value-added chemicals and/or biofuels, in the context of the so-called lignocellulose biorefinery. ${ }^{4-7}$

The key for exploiting the chemical value of lignocellulosic feedstocks, including coir, is to depolymerize the lignocellulosic matrix to obtain smaller molecules that can be utilized or further converted to platform chemicals and/or biofuels. However, the presence of lignin, an aromatic, highly complex and amorphous polymer, constitutes the major barrier against cost-effective lignocellulosic biofuels by complexing with hemicelluloses and cellulose and limiting the accessibility of enzymes to the polysaccharides, thus reducing the efficiency of the hydrolysis/saccharification. ${ }^{8,9}$ Pretreatment of lignocellulosic materials to remove or modify the lignin is therefore needed to enhance the hydrolysis of carbohydrates. The efficiency of the pretreatment methods is highly dependent on the lignin structure, and hence the knowledge of the exact structure of the lignin polymer is important to develop appropriate pretreatment methods for lignin modification and/or removal.

Lignin is a complex polymer synthesized by enzymatic polymerization of three main precursors, the monolignols $p$ coumaryl (4-hydroxycinnamyl), coniferyl (4-hydroxy-3-methoxycinnamyl), and sinapyl (4-hydroxy-3,5-dimethoxycinnamyl) alcohols. ${ }^{10}$ These monolignols produce the $p$-hydroxyphenyl $(\mathrm{H})$, guaiacyl $(\mathrm{G})$, and syringyl $(S)$ phenylpropanoid lignin units when incorporated into the lignin polymer, in which they are linked by several types of $\mathrm{C}-\mathrm{C}$ and ether bonds. The lignin composition depends on the botanical origin. Thus, hardwood lignins are composed of $S$ and $G$ units in varying ratios, softwood lignins are primarily composed of $\mathrm{G}$ units and a small amount of $\mathrm{H}$ units, and grass lignins include the three units (together with ferulates and $p$-coumarates). The $\mathrm{H}$-unit content is usually small (typically $<5 \%$ ), but it is often reported as being higher because of conflation with various other $p$-hydroxyphenyl units that do not arise from the incorporation of $p$-coumaryl alcohol into the lignin. ${ }^{11,12}$

Previous papers have reported the high lignin content of coconut coir (around 33\%); ${ }^{3}$ however, the composition and structure of the lignin has not yet been studied. In this paper, we perform a detailed characterization of the lignin of coconut coir. A main challenge in elucidating the structure of lignins is obtaining high-yield isolation in a chemically unaltered form. The "milled-wood lignin" (MWL) is a lignin preparation considered to be the most representative of the whole native lignin in the plant, ${ }^{13}$ despite its low yield and the possibility of some modifications during isolation, especially during the milling process. ${ }^{14}$ In this work, the MWL was isolated from

Received: November 2, 2012

Revised: February 5, 2013

Accepted: February 12, 2013

Published: February 12, 2013 
coconut coir and subsequently analyzed by an array of analytical techniques, including pyrolysis-gas chromatography/mass spectrometry (Py-GC/MS) in the absence and in the presence of tetramethylammonium hydroxide (TMAH), 2D NMR, thioacidolysis (followed by Raney nickel desulfurization), and derivatization followed by reductive cleavage (DFRC). Py-GC/MS is a rapid and sensitive analytical method for analyzing the composition of lignin in terms of its $H, G$, and $S$ units. ${ }^{15-17}$ However, the presence of $p$-hydroxycinnamates ( $p$-coumarates and ferulates) or $p$-hydroxybenzoates, which are abundant in the lignins of many plants, ${ }^{11,12,15,18,19}$ constitutes a complication for lignin analysis by analytical pyrolysis, as they yield products similar to those from lignins. This problem can however be solved by using pyrolysis in the presence of tetramethylammonium hydroxide (TMAH), which avoids decarboxylation and releases intact fully methylated derivatives. $^{11,12,15,19,20}$ Additional information regarding the different lignin units and interunit linkages present was provided by $2 \mathrm{D}$ NMR spectroscopy, a powerful tool for lignin structural characterization. $^{12,21-32}$ Thioacidolysis is a selective chemical degradative method that cleaves the most frequent interunit linkage in lignins, i.e., the $\beta-\mathrm{O}-4^{\prime}$ ether linkage. The total yields and relative distribution of the thioacidolysis monomers reflect the amount and ring type $(\mathrm{S}, \mathrm{G}$, or $\mathrm{H})$ of lignin units involved in these alkyl aryl ether bonds. In addition, the dimers recovered after thioacidolysis can provide information about the units involved in the various carbon-carbon and diaryl ether linkages, often referred to as the "condensed" lignin bonds (including $5-5^{\prime}, 4-\mathrm{O}-5^{\prime}, \beta-1^{\prime}, \beta-5^{\prime}$, and $\left.\beta-\beta^{\prime}\right) .^{33-35}$ Finally, DFRC provided additional information regarding the nature and extent of $\gamma$-acylation of the lignin side chain. ${ }^{36-39}$ Detailed knowledge of the composition and structure of coconut coir lignin will help to maximize the exploitation of this important food crop waste as a feedstock for different biorefinery processes.

\section{MATERIALS AND METHODS}

Samples. The coconut (C. nucifera) coir fibers selected for this study were supplied by the CELESA pulp mill (Tortosa, Spain). The air-dried fibers were ground in an IKA MF10 cutting mill to pass through a 100-mesh screen and were subsequently extracted with acetone in a Soxhlet apparatus for $8 \mathrm{~h}$ and with hot water $(3 \mathrm{~h}$ at 100 ${ }^{\circ} \mathrm{C}$ ). Klason lignin content was estimated as the residue after sulfuric acid hydrolysis of the pre-extracted material, corrected for ash and protein content, according to the TAPPI method T222 om $-88 .{ }^{40}$ The acid-soluble lignin was determined, after the insoluble lignin was filtered off (Duran filter crucible 4; nominal pore size max. 10-16 $\mu \mathrm{m})$, by UV-spectroscopic determination at $205 \mathrm{~nm}$ wavelength using $110 \mathrm{~L} \mathrm{~cm}^{-1} \mathrm{~g}^{-1}$ as the extinction coefficient. Ash content was estimated as the residue after $6 \mathrm{~h}$ of heating at $525^{\circ} \mathrm{C}$, according to the TAPPI method T211 om- $02 .^{40}$ Three replicates were used for each sample.

MWL Isolation. The lignins were obtained according to the classical procedure. ${ }^{13}$ Extractive-free material $(40 \mathrm{~g})$ was finely ballmilled in a Retsch S100 centrifugal ball mill at $400 \mathrm{rpm}(3 \times 15 \mathrm{~h})$ using an agate jar and balls. The ball-milled material was then extracted with dioxane-water $(9: 1, \mathrm{v} / \mathrm{v})(20 \mathrm{~mL}$ of solvent/g of milled fiber). The solution was centrifuged and the supernatant subsequently evaporated to dryness at $40{ }^{\circ} \mathrm{C}$ at reduced pressure. The residue obtained (raw MWL) was redissolved into a solution of acetic acid/ water 9:1 (v/v) $(25 \mathrm{~mL}$ of solvent/g of raw MWL). The lignin from the solution was precipitated into water, and the formed precipitate was separated by centrifugation, milled in an agate mortar, and subsequently dissolved in a solution of 1,2-dichloroethane:ethanol $(1: 2, \mathrm{v} / \mathrm{v})$. The mixture was then centrifuged to eliminate the insoluble material. The lignin in the supernatant was precipitated into diethyl ether, and the obtained residue was separated by centrifugation. This residue was then resuspended in diethyl ether, centrifuged, and finally resuspended in petroleum ether. The final purified MWL sample was recovered by centrifugation and dried under a $\mathrm{N}_{2}$ current. The final yields ranged from 10 to $12 \%$ of the original Klason lignin content.

Gel Permeation Chromatography (GPC). GPC was performed on a Shimadzu LC-20A liquid chromatography (LC) system (Shimadzu, Kyoto, Japan) equipped with a photodiode array (PDA) detector (SPD-M20A; Shimadzu) using the following conditions: column, TSK gel $\alpha-\mathrm{M}+\alpha-2500$ (Tosoh, Tokyo, Japan); eluent, $0.1 \mathrm{M}$

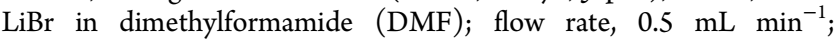
temperature, $40{ }^{\circ} \mathrm{C}$; sample detection, PDA response at $280 \mathrm{~nm}$. The data acquisition and computation used LCsolution version 1.25 software (Shimadzu). The molecular weight calibration was via polystyrene standards $\left(M_{\mathrm{w}}\right.$ range from $2.66 \times 10^{2}$ up to $3.84 \times 10^{6}$ Da, Tosoh Bioscience).

Analytical Pyrolysis. Pyrolysis of MWL (approximately $100 \mu \mathrm{g}$ ) was performed with a 2020 microfurnace pyrolyzer (Frontier Laboratories Ltd.) connected to an Agilent $6890 \mathrm{GC} / \mathrm{MS}$ using a DB-1701 fused-silica capillary column $(30 \mathrm{~m} \times 0.25 \mathrm{~mm}$ i.d., $0.25 \mu \mathrm{m}$ film thickness) and an Agilent 5973 mass selective detector (EI at 70 $\mathrm{eV}$ ). The pyrolysis was performed at $500{ }^{\circ} \mathrm{C}$. The oven temperature was programmed from $50{ }^{\circ} \mathrm{C}(1 \mathrm{~min})$ to $100{ }^{\circ} \mathrm{C}$ at $30^{\circ} \mathrm{C} \mathrm{min}-1$ and then to $300{ }^{\circ} \mathrm{C}(10 \mathrm{~min})$ at $10^{\circ} \mathrm{C} \mathrm{min}^{-1}$. Helium was the carrier gas $(1$ $\left.\mathrm{mL} \min ^{-1}\right)$. The compounds were identified by comparing their mass spectra with those of the Wiley and NIST libraries and those reported in the literature. ${ }^{16,17}$ Peak molar areas were calculated for the lignin degradation products, the summed areas were normalized, and the data for three repetitive analyses were averaged and expressed as percentages. The relative standard deviation for the pyrolysis data was less than $5 \% .^{11,12,15}$

NMR Spectroscopy. 2D NMR spectra were recorded at $25^{\circ} \mathrm{C}$ on a Bruker AVANCE III $500 \mathrm{MHz}$ instrument, equipped with a cryogenically cooled $5 \mathrm{~mm}$ TCI gradient probe with inverse geometry (proton coils closest to the sample). Unacetylated MWL ( $40 \mathrm{mg}$ ) was dissolved in $0.75 \mathrm{~mL}$ of dimethyl sulfoxide (DMSO) $-d_{6}$, or $80 \mathrm{mg}$ of acetylated MWL (after $48 \mathrm{~h}$ treatment in acetic anhydride/pyridine, $1: 1 \mathrm{v} / \mathrm{v}$, and recovered by precipitation into water) was dissolved in $0.75 \mathrm{~mL}$ of chloroform- $d$. The central solvent peaks were used as internal reference (DMSO $\delta_{\mathrm{C}} / \delta_{\mathrm{H}} 39.5 / 2.49$; chloroform, $\delta_{\mathrm{C}} / \delta_{\mathrm{H}} 77.0 /$ 7.26). The HSQC (heteronuclear single quantum coherence) experiment on the unacetylated sample used Bruker's "hsqcetgpsisp2.2" pulse program (adiabatic-pulsed version) with spectral widths of $5000 \mathrm{~Hz}$ (from 10 to $0 \mathrm{ppm}$ ) and $20843 \mathrm{~Hz}$ (from 165 to $0 \mathrm{ppm}$ ) for the ${ }^{1} \mathrm{H}$ and ${ }^{13} \mathrm{C}$ dimensions. The number of transients was 64, and 256 time increments were always recorded in the ${ }^{13} \mathrm{C}$ dimension. The ${ }^{1} J_{\mathrm{CH}}$ used was $145 \mathrm{~Hz}$. Processing used typical matched Gaussian apodization in the ${ }^{1} \mathrm{H}$ dimension and squared cosine-bell apodization in the ${ }^{13} \mathrm{C}$ dimension. Prior to Fourier transformation, the data matrices were zero-filled up to 1024 points in the ${ }^{13} \mathrm{C}$ dimension. The HMBC (heteronuclear multiple bond correlation) experiment on the acetylated sample used Bruker's "hmbcgplpndqf" pulse program and a long-range J-coupling evolution time of $70 \mathrm{~ms}$.

Two-dimensional NMR cross-signals were assigned by literature comparison. ${ }^{12,21-32}$ A semiquantitative analysis of the volume integrals of the HSQC correlation peaks was performed using Bruker's Topspin 3.1 processing software. Integration of signals corresponding to chemically analogous $\mathrm{C}-\mathrm{H}$ pairs with similar ${ }^{1} J_{\mathrm{CH}}$ coupling values was performed separately for the different regions of the spectra. In the aliphatic oxygenated region, interunit linkages were estimated from $\mathrm{C}_{\alpha}-\mathrm{H}_{\alpha}$ correlations, except for structure $\mathrm{E}$ described below where $\mathrm{C}_{\gamma}-$ $\mathrm{H}_{\gamma}$ correlations had to be used, and the relative abundance of side chains involved in different substructures and terminal structures were calculated. In the aromatic/unsaturated region, $\mathrm{C}_{2}-\mathrm{H}_{2}$ correlations from $\mathrm{H}, \mathrm{G}$, and $\mathrm{S}$ lignin units and from $p$-hydroxybenzoates were used to estimate their abundances (note that $p$-hydroxybenzoate quantitation relative to the lignin might be overestimated because of the longer relaxation times of these end-units compared to the rapidly relaxing polymer and the more extensive relaxation the latter 
experiences during the significant duration of the pulse experiment itself). An estimation of the percentage of $\gamma$-acylation of the lignin side chain was performed by integration of the signals corresponding to the hydroxylated vs acylated $\gamma$-C/H correlations.

Thioacidolysis. Thioacidolysis of $5 \mathrm{mg}$ of MWL was performed according to the described protocol ${ }^{33}$ using $0.2 \mathrm{M} \mathrm{BF}_{3}$ etherate in dioxane/ethanethiol 8.75:1. The reaction products were extracted with dichloromethane, dried, and concentrated. GC analysis of trimethylsilylated samples [using $\mathrm{N}, \mathrm{O}$-bis(trimethylsilyl)trifluoroacetamide, BSTFA], was performed with a Hewlett-Packard 6890 instrument using an Rtx 5 column from Restec Corporation $(45 \mathrm{~m} \times 0.32 \mathrm{~mm}$ i.d., $0.25 \mu \mathrm{m}$ film thickness) and a flame-ionization detector. The temperature was programmed from $180{ }^{\circ} \mathrm{C}$ to $270{ }^{\circ} \mathrm{C}(15 \mathrm{~min})$ at $40{ }^{\circ} \mathrm{C} \mathrm{min}{ }^{-1}$ and then to $300{ }^{\circ} \mathrm{C}(5 \mathrm{~min})$ at $4{ }^{\circ} \mathrm{C} \mathrm{min}^{-1}$. Injector and detector were at $250^{\circ} \mathrm{C}$ and $280^{\circ} \mathrm{C}$, respectively, and helium was the carrier gas.

Desulfurization of Thioacidolysis Degradation Products. Two-hundred microliters of the $\mathrm{CH}_{2} \mathrm{Cl}_{2}$ solution containing the thioacidolysis products was desulfurized with $1 \mathrm{~mL}$ of Raney nickel aqueous slurry and $5 \mathrm{~mL}$ of methanol, as previously described. ${ }^{34}$ The desulfurization was allowed to proceed at $80^{\circ} \mathrm{C}$ (oil bath) for $4 \mathrm{~h}$ with occasional shaking. GC/MS analysis of the dimeric compounds (as their trimethylsilyl ether derivatives) was performed on a Varian Star 3400 coupled to an ion-trap Varian Saturn 2000 detector, using a DB$5 \mathrm{HT}$ fused-silica capillary column from J\&W Scientific $(30 \mathrm{~m} \times 0.25$ $\mathrm{mm}$ i.d., $0.1 \mu \mathrm{m}$ film thickness). The temperature was programmed from $50{ }^{\circ} \mathrm{C}$ to $110^{\circ} \mathrm{C}$ at $30^{\circ} \mathrm{C} \mathrm{min}^{-1}$ and then to $320^{\circ} \mathrm{C}(13 \mathrm{~min})$ at $6{ }^{\circ} \mathrm{C} \mathrm{min}{ }^{-1}$. The injector and transfer line were at $300^{\circ} \mathrm{C}$; the injector was programmed from $120^{\circ} \mathrm{C}(0.1 \mathrm{~min})$ to $380{ }^{\circ} \mathrm{C}$ at $200{ }^{\circ} \mathrm{C} \mathrm{min}{ }^{-1}$. Helium was the carrier gas $\left(2 \mathrm{~mL} \mathrm{~min}^{-1}\right)$, and tetracosane was used as internal standard. Dimer identification was based on previously reported mass spectra ${ }^{21,34,41-43}$ and mass fragmentography.

DFRC. To assess the incorporation of naturally acetylated monolignols into the lignin, resulting in $\gamma$-acetylated lignin side chains, a modification of the standard DFRC method using propionylating instead of acetylating reagents ${ }^{39}$ was made in the present study. Lignins $\left(10 \mathrm{mg}\right.$ ) were stirred for $2 \mathrm{~h}$ at $50{ }^{\circ} \mathrm{C}$ with propionyl bromide in propionic acid $(8: 92, \mathrm{v} / \mathrm{v})$. The solvents and excess bromide were removed by rotary evaporation. The products were then dissolved in dioxane/propionic acid/water (5:4:1, v/v/v), and $50 \mathrm{mg}$ powdered $\mathrm{Zn}$ was added. After being stirred for $40 \mathrm{~min}$ at room temperature, the mixture was transferred into a separatory funnel with dichloromethane and saturated ammonium chloride. The aqueous phase was adjusted to $\mathrm{pH}<3$ by adding $3 \% \mathrm{HCl}$, the mixture vigorously mixed, and the organic layer separated. The water phase was extracted twice more with dichloromethane. The combined dichloromethane fractions were dried over anhydrous $\mathrm{NaSO}_{4}$, and the filtrate was evaporated to dryness using a rotary evaporator. The residue was subsequently propionylated for $1 \mathrm{~h}$ in $1.1 \mathrm{~mL}$ of dichloromethane containing $0.2 \mathrm{~mL}$ of propionic anhydride and $0.2 \mathrm{~mL}$ of pyridine. The propionylated (and naturally acetylated) lignin degradation compounds were collected after rotary evaporation of the solvents and subsequently analyzed by GC/MS.

The GC/MS analyses were performed with an Agilent 7820A chromatograph coupled to an Agilent 5975 mass detector, using a capillary column (Agilent HP- $5 \mathrm{~ms}, 30 \mathrm{~m} \times 0.25 \mathrm{~mm}$ i.d., $0.25 \mu \mathrm{m}$ film thickness). The oven was heated from $140{ }^{\circ} \mathrm{C}(1 \mathrm{~min})$ to 280 at $3{ }^{\circ} \mathrm{C}$ $\mathrm{min}^{-1}$, ramped at $20{ }^{\circ} \mathrm{C} \mathrm{min}^{-1}$ to $300{ }^{\circ} \mathrm{C}$, and then held for $5 \mathrm{~min}$ at the final temperature. The injector was set at $250{ }^{\circ} \mathrm{C}$, and the transfer line was kept at $280^{\circ} \mathrm{C}$. Helium was used as the carrier gas at a rate of $2 \mathrm{~mL} \min ^{-1}$.

\section{RESULTS AND DISCUSSION}

The relative abundances of the main constituents of coir are presented in Table 1. The high lignin content observed (32.1\%) agrees well with previously published data. ${ }^{3}$ In this work, we have thoroughly studied the coconut coir lignin composition and structure. For this purpose, the MWL was isolated according to the traditional lignin isolation proce-
Table 1. Abundance of the Main Constituents of Coconut Coir (\% of dry weight)

$\begin{array}{lc}\text { water-solubles } & 1.7 \\ \text { acetone extractives } & 0.3 \\ \text { Klason lignin }^{a} & 32.1 \\ \text { acid-soluble lignin }^{c} & 1.4 \\ \text { carbohydrates }^{b} & 62.9 \\ \text { ash } & 1.6\end{array}$

${ }^{a}$ Corrected for proteins and ash. ${ }^{b}$ Determined by subtracting other components from $100 \%$

dure, ${ }^{13}$ and subsequently analyzed by GPC, Py-GC/MS, 2D NMR, thioacidolysis, and DFRC. As said before, MWL preparation is considered to be the most representative of the whole native lignin in the plant. However, we must keep in mind that the results obtained here reflect the structure of isolated MWL, which represents only a part of the whole lignin in the plant.

Molecular Weight Distribution of Coconut Coir MWL. The molecular weight-average $\left(M_{\mathrm{w}}\right)$ and number-average $\left(M_{\mathrm{n}}\right)$ values were estimated from the GPC curves (relative values related to polystyrene standards). The MWL exhibited a $M_{\mathrm{w}}$ of $7900 \mathrm{~g} \mathrm{~mol}^{-1}$ and a $M_{\mathrm{n}}$ molecular weight of $2900 \mathrm{~g} \mathrm{~mol}^{-1}$. Therefore, the MWL exhibited relatively narrow polydispersity, with $M_{\mathrm{w}} / M_{\mathrm{n}}$ of 2.7 compared to other isolated lignins. ${ }^{44}$

Py-GC/MS. The MWL from coconut coir was analyzed by Py-GC/MS. The pyrogram is shown in Figure 1a, and the identities and relative molar abundances of the released compounds are listed in Table 2. Pyrolysis of coir MWL released phenolic compounds that are derived from $\mathrm{H}, \mathrm{G}$ and $\mathrm{S}$ lignin units, the most predominant ones being phenol (1), guaiacol (4), 4-methylguaiacol (6), 4-vinylguaiacol (9), syringol (10), vanillin (13), trans-isoeugenol (15), and trans-coniferaldehyde (31). The pyrolysis data indicate a predominance of G- over S-lignin units, with a S/G ratio of 0.29 . In addition, high levels of phenol ( $\sim 27 \%$ of all phenolic compounds) were released upon pyrolysis from coconut coir MWL. This fact might suggest the presence of $p$-hydroxybenzoates in coir lignin, as also occurs in the lignin of other palms. ${ }^{19}$ It is important to note that $p$-hydroxybenzoates decarboxylate upon pyrolysis $^{19,20}$ and produce similar compounds as those derived from $p$-hydroxyphenyl lignin, such as phenol, which will overestimate the relative abundance of $\mathrm{H}$-lignin units. It is obvious then that the abundance of phenol cannot be used here for the estimation of the lignin $\mathrm{H}: \mathrm{G}: \mathrm{S}$ composition upon Py$\mathrm{GC} / \mathrm{MS}$, as the major part of it does not arise from the core lignin structural units but from $p$-hydroxybenzoates, as will be shown below.

The occurrence of $p$-hydroxybenzoates in the lignin of coconut coir was assessed by pyrolysis in the presence of TMAH as methylating agent. Py/TMAH efficiently prevents decarboxylation and results in depolymerization and subsequent methylation of the phenolic and carboxyl groups. ${ }^{11,12,20}$ Py/TMAH of coconut coir lignin (shown in Figure $1 \mathrm{~b}$ ) released significant levels of 4-methoxybenzoic acid methyl ester, confirming the occurrence of $p$-hydroxybenzoates in this lignin. In contrast, the amounts methoxybenzene, which arises exclusively from $\mathrm{H}$-lignin, were very low (only $2 \%$ of the 4 methoxybenzoic acid methyl ester peak area). This means that the great majority of phenols released after Py-GC/MS arise from $p$-hydroxybenzoates. The occurrence of $p$-hydroxybenzoates in the lignin of other plants, such as sago palm, was also 

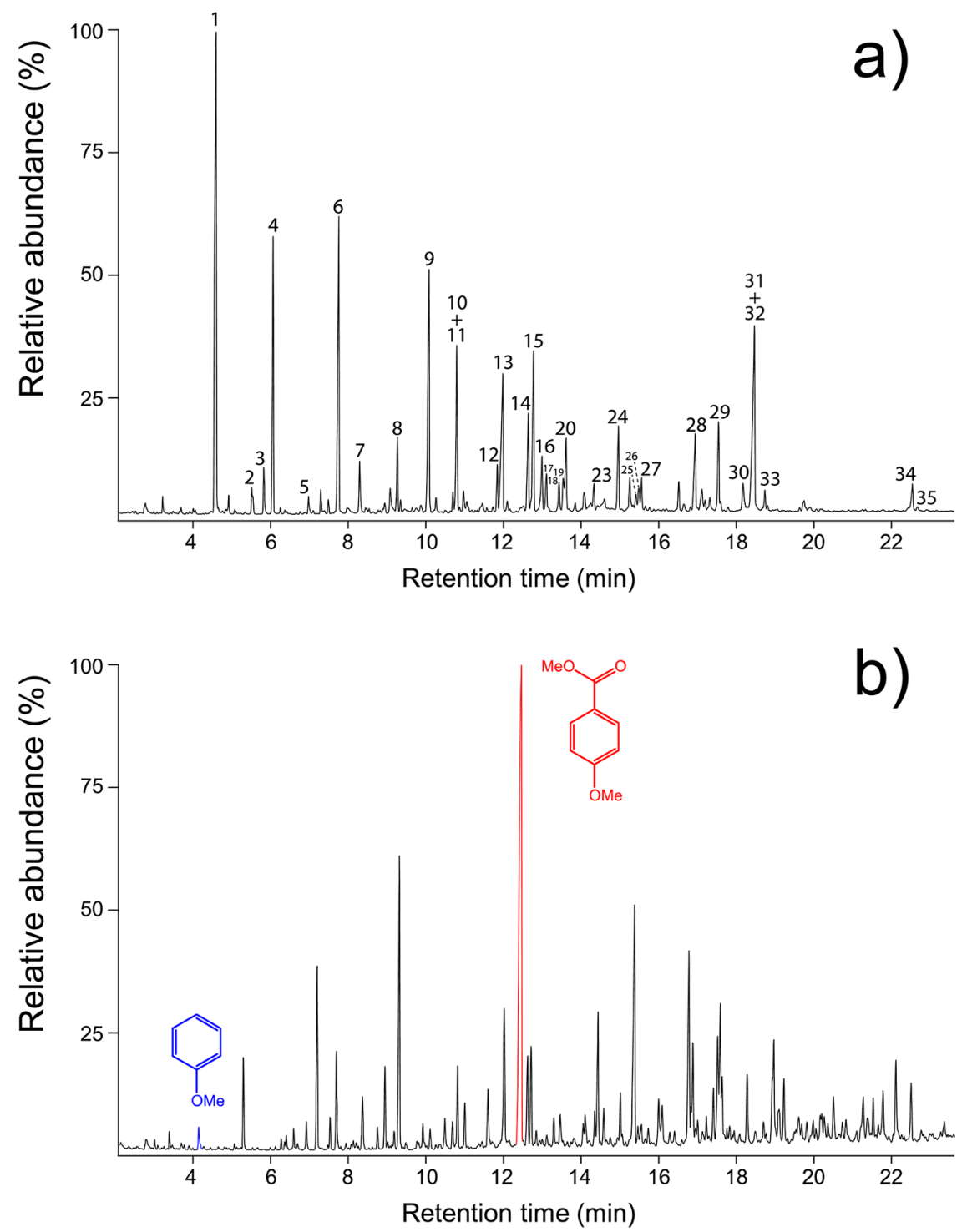

Figure 1. Py-GC/MS (a) and Py-TMAH-GC/MS (b) chromatograms of the MWL isolated from coconut coir. The identities and relative abundances of the compounds released by Py-GC/MS are listed in Table 2. Only the identities of peaks of interest (methoxybenzene and 4methoxybenzoic acid methyl ester) are shown in the case of Py-TMAH-GC/MS.

successfully determined by Py/TMAH. ${ }^{19}$ Only minor amounts of $p$-coumarates ( $2 \%$ with respect to $p$-hydroxybenzoates) could be detected (as the dimethyl derivative) in coir lignin upon Py/TMAH.

2D NMR. To obtain additional information on the structure of coir lignin, the MWL was analyzed by $2 \mathrm{D}$ NMR, which provides information on the interunit linkages as well as the lignin composition. The side chain $\left(\delta_{\mathrm{C}} / \delta_{\mathrm{H}} 50-90 / 2.5-6.0\right)$ and the aromatic/unsaturated $\left(\delta_{\mathrm{C}} / \delta_{\mathrm{H}} 90-155 / 6.0-8.5\right)$ regions of the HSQC NMR spectrum of the MWL from coconut coir are shown in Figure 2. The main lignin crosssignals assigned in the HSQC spectrum are listed in Table 3, and the main substructures present are also depicted in the Figure 2.

The side chain region of the spectrum gives useful information about the different interunit linkages present in the lignin (Figure 2a). The spectrum shows prominent signals corresponding to $\beta-\mathrm{O}-4^{\prime}$ alkyl-aryl ether linkages (substructures $\mathrm{A}$ and $\mathrm{A}^{\prime}$ ). The $\mathrm{C}_{\alpha}-\mathrm{H}_{\alpha}$ correlations in $\beta-\mathrm{O}-4^{\prime}$ substructures were observed in overlapping signals at $\delta_{\mathrm{C}} / \delta_{\mathrm{H}}$
71.0/4.75 and 71.7/4.87 for structures linked to $\mathrm{G}$ or $\mathrm{S}$ ligninunits. Likewise, the $\mathrm{C}_{\beta}-\mathrm{H}_{\beta}$ correlations were observed at $\delta_{\mathrm{C}} / \delta_{\mathrm{H}}$ 83.9/4.28 for $\beta-\mathrm{O}-4^{\prime}-\mathrm{G}$ units and at $\delta_{\mathrm{C}} / \delta_{\mathrm{H}} 85.9 / 4.12$ for $\beta-$ $\mathrm{O}-4^{\prime}-\mathrm{S}$ units; $\mathrm{C}_{\beta}-\mathrm{H}_{\beta}$ correlations for $\beta-\mathrm{O}-4^{\prime}-\mathrm{H}$ units were observed at $\delta_{\mathrm{C}} / \delta_{\mathrm{H}} 83.3 / 4.48$. The $\mathrm{C}_{\gamma}-\mathrm{H}_{\gamma}$ correlations in $\beta-$ O-4' substructures were observed at $\delta_{\mathrm{C}} / \delta_{\mathrm{H}} 59.8 / 3.24$ and 3.61, partially overlapped with other signals. In addition, the spectrum clearly showed the presence of signals in the range $\delta_{\mathrm{C}} / \delta_{\mathrm{H}} 63.3 / 4.46-4.30$ corresponding to the $\mathrm{C}_{\gamma}-\mathrm{H}_{\gamma}$ correlations of $\gamma$-acylated units (substructure $\mathrm{A}^{\prime}, \mathrm{R}=\mathrm{acyl}$ ). The HSQC spectrum therefore indicates that the coconut coir lignin is partially acylated at the $\gamma$-position of the lignin side chain. Signals for $\alpha$-acylated $\beta-\mathrm{O}-4^{\prime}$ substructures, which should appear at $\sim 6.1 / 75 \mathrm{ppm}$, were not observed in the spectrum. Therefore, it is possible to conclude that the lignin of coconut coir MWL is partially acylated and that this acylation occurs exclusively at the $\gamma$-position of the lignin side chain. An estimation of the percentage of $\gamma$-acylation of the lignin side chain was performed by integration of the signals correspond- 
Table 2. Identities and Relative Molar Abundances of the Compounds Released after Py-GC/MS of Coconut Coir MWL $^{a, b}$

\begin{tabular}{|c|c|c|c|}
\hline label & compound & origin & rel abundance \\
\hline 1 & phenol & $\mathrm{LH} / \mathrm{PB}$ & 27.1 \\
\hline 2 & 3-methylphenol & $\mathrm{LH}$ & 0.7 \\
\hline 3 & 4-methylphenol & $\mathrm{LH}$ & 1.6 \\
\hline 4 & guaiacol & LG & 7.8 \\
\hline 5 & 4-ethylphenol & $\mathrm{LH}$ & 0.5 \\
\hline 6 & 4-methylguaiacol & LG & 9.2 \\
\hline 7 & 4-vinylphenol & $\mathrm{LH}$ & 1.8 \\
\hline 8 & 4-ethylguaiacol & LG & 1.7 \\
\hline 9 & 4-vinylguaiacol & LG & 8.0 \\
\hline 10 & syringol & LS & 3.4 \\
\hline 11 & eugenol & LG & 0.9 \\
\hline 12 & cis-isoeugenol & LG & 1.0 \\
\hline 13 & vanillin & LG & 5.7 \\
\hline 14 & 4-methylsyringol & LS & 2.6 \\
\hline 15 & trans-isoeugenol & LG & 4.5 \\
\hline 16 & homovanillin & LG & 1.6 \\
\hline 17 & 4-hydroxybenzoic acid methyl ester & LH & 1.0 \\
\hline 18 & propyneguaiacol & LG & 0.7 \\
\hline 19 & propyneguaiacol & LG & 0.7 \\
\hline 20 & acetovanillone & LG & 1.9 \\
\hline 21 & ethylsyringol & LS & 0.3 \\
\hline 22 & vanillic acid methyl ester & LG & 0.2 \\
\hline 23 & guaiacylacetone & LG & 0.6 \\
\hline 24 & vinylsyringol & LS & 2.1 \\
\hline 25 & propiovanillone & LG & 0.3 \\
\hline 26 & guaiacyl vinyl ketone & LG & 0.5 \\
\hline 27 & 4-allylsyringol & LS & 0.5 \\
\hline 28 & syringaldehyde & LS & 2.2 \\
\hline 29 & trans-propenylsyringol & LS & 1.9 \\
\hline 30 & acetosyringone & LS & 0.8 \\
\hline 31 & trans-coniferaldehyde & LG & 4.3 \\
\hline 32 & trans-coniferyl alcohol & LG & 2.7 \\
\hline 33 & syringylacetone & LS & 0.3 \\
\hline 34 & trans-sinapaldehyde & LS & 0.6 \\
\hline 35 & trans-sinapyl alcohol & LS & 0.1 \\
\hline
\end{tabular}

${ }^{a} \mathrm{~S} / \mathrm{G}$ ratio $=0.29 .{ }^{b} \mathrm{LH}: \mathrm{H}$ lignin units; LG: G lignin units; LS: S lignin units; PB: $p$-hydroxybenzoates.

ing to the $\mathrm{C}_{\gamma}-\mathrm{H}_{\gamma}$ correlations of hydroxylated vs acylated $\gamma$ carbon, indicating up to $11 \%$ of lignin acylation.

Strong signals for phenylcoumaran substructures (B) were also found in the spectrum of coconut coir MWL, the signals for their $\mathrm{C}_{\alpha}-\mathrm{H}_{\alpha}$ and $\mathrm{C}_{\beta}-\mathrm{H}_{\beta}$ correlations being observed at $\delta_{\mathrm{C}} /$ $\delta_{\mathrm{H}} 86.8 / 5.46$ and 53.1/3.45, and those of $\mathrm{C}_{\gamma}-\mathrm{H}_{\gamma}$ correlations overlapping with other signals around $\delta_{\mathrm{C}} / \delta_{\mathrm{H}} 62.6 / 3.71$. Resinol substructures $(\mathrm{C})$ were also clearly observed in the spectrum, with their $\mathrm{C}_{\alpha}-\mathrm{H}_{\alpha}, \mathrm{C}_{\beta}-\mathrm{H}_{\beta}$, and the double $\mathrm{C}_{\gamma}-\mathrm{H}_{\gamma}$ correlations at $\delta_{\mathrm{C}} / \delta_{\mathrm{H}} 84.9 / 4.67,53.5 / 3.06$, and $71.0 / 3.82$ and 4.18 (i.e., the two diastereotopic protons attached to the $\gamma$-carbon are well separated). Small signals corresponding to dibenzodioxocin substructures (D) were also observed in the spectra, their $\mathrm{C}_{\alpha}-$ $\mathrm{H}_{\alpha}$ and $\mathrm{C}_{\beta}-\mathrm{H}_{\beta}$ correlations being at $\delta_{\mathrm{C}} / \delta_{\mathrm{H}} 83.2 / 4.84$ and $85.4 /$ 3.87. Finally, other signals observed in the side chain region of the spectrum corresponded to the $\mathrm{C}_{\gamma}-\mathrm{H}_{\gamma}$ correlations of cinnamyl alcohol end-groups $(\mathrm{E})$ at $\delta_{\mathrm{C}} / \delta_{\mathrm{H}} 61.4 / 4.09$.

The main cross-signals in the aromatic region of the HSQC spectrum (Figure $2 \mathrm{~b}$ ) corresponded to the aromatic rings of the different $\mathrm{H}, \mathrm{G}$, and $\mathrm{S}$ lignin units and to $p$-hydroxybenzoates that are attached to the lignin (see below). The S-lignin units showed a prominent signal for the $\mathrm{C}_{2,6}-\mathrm{H}_{2,6}$ correlation at $\delta_{\mathrm{C}}$ / $\delta_{\mathrm{H}} 103.9 / 6.71$, whereas the $\mathrm{G}$ units showed different correlations for $\mathrm{C}_{2}-\mathrm{H}_{2}\left(\delta_{\mathrm{C}} / \delta_{\mathrm{H}} 110.9 / 7.00\right)$ and $\mathrm{C}_{5}-\mathrm{H}_{5} / \mathrm{C}_{6}-$ $\mathrm{H}_{6}\left(\delta_{\mathrm{C}} / \delta_{\mathrm{H}} 115.0 / 6.74\right.$ and 6.94, and $\left.\delta_{\mathrm{C}} / \delta_{\mathrm{H}} 118.8 / 6.79\right)$. Signals corresponding to $\mathrm{C}_{3,5}-\mathrm{H}_{3,5}$ and $\mathrm{C}_{2,6}-\mathrm{H}_{2,6}$ correlations in $\mathrm{H}$ lignin units were observed at $\delta_{\mathrm{C}} / \delta_{\mathrm{H}} 106.8 / 7.32$ and 127.8/7.20. Strong signals for the $\mathrm{C}_{2,6}-\mathrm{H}_{2,6}$ and $\mathrm{C}_{3,5}-\mathrm{H}_{3,5}$ correlations of $p$ hydroxybenzoate units were observed at $\delta_{\mathrm{C}} / \delta_{\mathrm{H}} 131.2 / 7.68$ and $114.3 / 6.61$ (the latter overlapping with the $G_{5} / G_{6}$ signals). Other signals in this HSQC region of the spectrum are from cinnamyl alcohol end-groups $(\mathrm{E})$, with their $\mathrm{C}_{\alpha}-\mathrm{H}_{\alpha}$ and $\mathrm{C}_{\beta}-$ $\mathrm{H}_{\beta}$ correlations observed at $\delta_{\mathrm{C}} / \delta_{\mathrm{H}} 129.0 / 6.23$ and $129.0 / 6.45$, and cinnamaldehyde end-groups (I), with the $\mathrm{C}_{\alpha}-\mathrm{H}_{\alpha}$ and $\mathrm{C}_{\beta}-$ $\mathrm{H}_{\beta}$ correlations observed at $\delta_{\mathrm{C}} / \delta_{\mathrm{H}} 153.8 / 7.63$ and $126.7 / 6.77$. The relative content of the cinnamaldehyde end-groups was estimated by comparison of the intensities of the $\mathrm{C}_{\beta}-\mathrm{H}_{\beta}$ correlations in cinnamyl alcohols (E) and aldehydes (I). Other cross-signals revealing the presence of coniferaldehyde end-groups corresponded to $\mathrm{C}_{2}-\mathrm{H}_{2}$ and $\mathrm{C}_{6}-\mathrm{H}_{6}$ correlation signals at $\delta_{\mathrm{C}} / \delta_{\mathrm{H}} 111.1 / 7.40$ and $\delta_{\mathrm{C}} / \delta_{\mathrm{H}} 123.6 / 7.21$. Interestingly, in this region of the HSQC spectrum, it was also possible to detect two signals at $\delta_{\mathrm{C}} / \delta_{\mathrm{H}} 94.1 / 6.56$ and $98.8 / 6.20$ corresponding to the $\mathrm{C}_{8}-\mathrm{H}_{8}$ and $\mathrm{C}_{6}-\mathrm{H}_{6}$ correlations of tricin $(\mathrm{T})$, a flavone that is apparently incorporated into the lignins in some grasses. ${ }^{12}$ Coconut, like the grasses, belongs to the monocots; it is beginning to appear that tricin may be a feature restricted to monocot lignins although its clade range remains to be determined.

The relative abundances of the main lignin interunit linkages and end-groups, as well as the percentage of $\gamma$-acylation of the lignin side chain, the molar abundances of the different lignin units $(\mathrm{H}, \mathrm{G}$, and $\mathrm{S})$ and of the $p$-hydroxybenzoates, and the molar $S / G$ ratio of the coir lignin, all estimated from volume integration of contours in the HSQC spectrum, are shown in Table 4. The main substructure present in the lignin of coconut coir was the $\beta-\mathrm{O}-4^{\prime}$ aryl ether $\left(\mathrm{A} / \mathrm{A}^{\prime}\right)$, that accounts for $82 \%$ of all interunit linkages, followed by $\beta-5^{\prime}$ phenylcoumaran substructures (B) that involved $13 \%$ of all linkages, $\beta-\beta^{\prime}$ resinol substructures (C) that involved $4 \%$, and a small amount of 5-5' dibenzodioxocin substructures (D) that involved $1 \%$ of all linkages. The lignin S/G ratio determined with NMR (0.23) was similar to that obtained with Py-GC/MS, as shown above. $p$-Hydroxybenzoates are known to acylate the $\gamma-\mathrm{OH}$ of the lignin side chain in many plants, including palms. ${ }^{19,32,45-49}$ The fact that the side chain of the lignin in coir is partially acylated at the $\gamma-\mathrm{OH}$ ( $11 \%$ of lignin side chains), together with the presence of significant amounts of $p$-hydroxybenzoates (13\% with respect to lignin), seems to indicate that these could also acylate the $\gamma-\mathrm{OH}$ in the lignin of coir. However, the HSQC spectrum only indicates that the lignin in coir is partially acylated at the $\gamma$-position and cannot provide information on the nature of the acyl group. For this purpose, we performed HMBC experiments that correlate protons with carbons separated by two or three bonds; such long-range coupling experiments give important information about the connectivity of the ester moiety to the lignin skeleton. The HMBC experiments were performed on acetylated MWL to reduce the viscosity of the lignin solutions and thus enhance the spectral properties. Figure 3 shows the section of the HMBC spectrum of (acetylated) coconut coir MWL for the correlations of the carbonyl carbon of $p$-hydroxybenzoates acylating the lignin $\gamma-$ $\mathrm{OH}$. The correlations of the carbonyl carbon at $\delta_{\mathrm{C}} 165.0$ with 

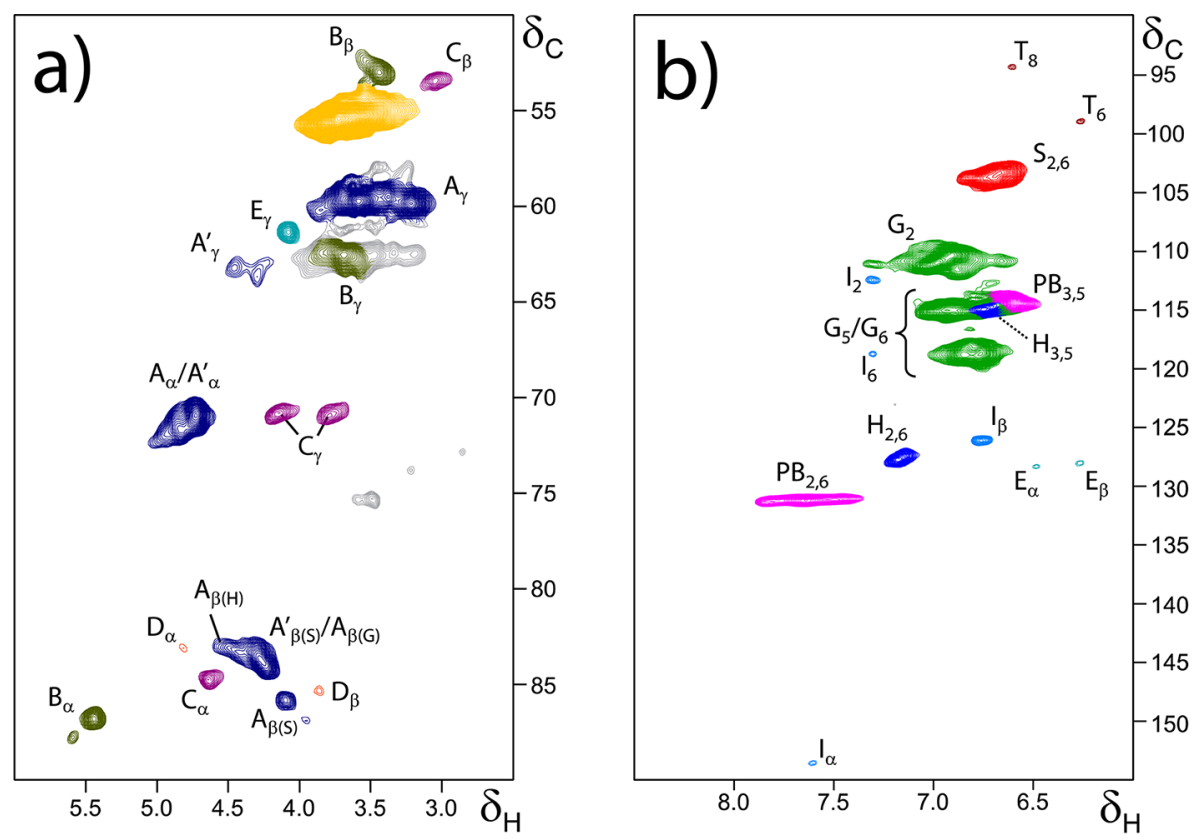

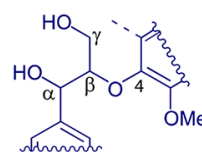

A

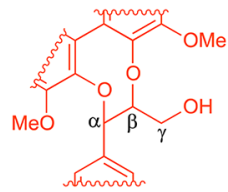

D<smiles>COC(=O)c1ccc(I)cc1</smiles>

PB

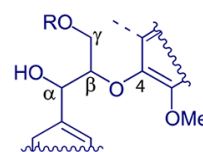

$A^{\prime}$

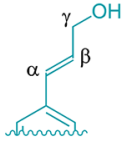

E<smiles>Cc1ccc(C)c(I)c1O</smiles>

$\mathrm{H}$

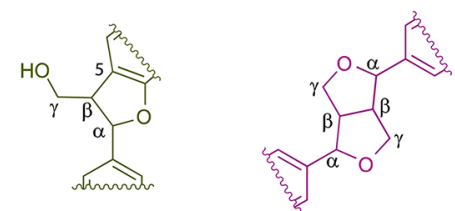

B

C

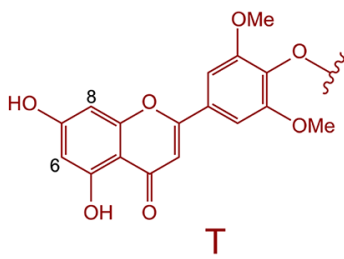<smiles>Cc1ccc(O)c(O)c1</smiles>

G

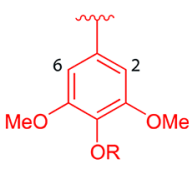

$\mathrm{S}$

Figure 2. Side chain (a) and aromatic (b) regions in the 2D-HSQC NMR spectrum of coconut coir MWL (in DMSO- $d_{6}$ ). See Table 3 for signal assignments. Main structures present in the lignin from the coconut coir: (A) $\beta-\mathrm{O}-4^{\prime}$ alkyl-aryl ethers; $\left(\mathrm{A}^{\prime}\right) \beta-\mathrm{O}-4^{\prime}$ alkyl-aryl ethers with acylated $\gamma-\mathrm{OH}$; (B) phenylcoumarans; (C) resinols; (D) dibenzodioxocins; (E) p-hydroxycinnamyl alcohol end-groups; (I) $p$-hydroxycinnamaldehyde endgroups; (T) tricin end-units; (PB) p-hydroxybenzoates; $(\mathrm{H}) \mathrm{H}$ units; (G) G units; (S) S units.

the 2- and 6-protons at $\delta_{\mathrm{H}} 7.68$ confirm that they belong to the $p$-hydroxybenzoates. In addition, the correlations of this carbonyl carbon with several protons in the range $\delta_{\mathrm{H}} 4.5-5.0$ conclusively demonstrate that $p$-hydroxybenzoates are acylating the $\gamma$-position of the lignin side chains in coir lignin, as also occurs in the lignins of other plants. ${ }^{19,32,45-49}$ On the other hand, it is known that the lignin of many plants are also acylated by acetate groups. ${ }^{50-54}$ This HMBC spectrum, however, could not show the correlations of the carbonyl carbon for native acetate groups that may be eventually acylating the $\gamma$-carbon of the lignin side chain in coir, as this lignin was acetylated for improving the spectral and solubility properties. Unfortunately the unacetylated materials are unsuitable for high quality $\mathrm{HMBC}$ experiments because of their rapid relaxation rates.

DFRC. Additional information regarding the presence of native acetate groups acylating the $\gamma-\mathrm{OH}$ of the lignin side chain in coconut coir MWL was obtained by DFRC analysis. The DFRC degradation method cleaves $\alpha$ - and $\beta$-ether linkages in the lignin polymer leaving $\gamma$-esters intact and is an appropriate and sensitive method for the analysis of natively $\gamma$-acylated lignin. ${ }^{36-38}$ The original DFRC degradation method does not allow the analysis of native acetylated lignin because the degradation products are acetylated during the degradation procedure, but with a modification by substituting acetylating reagents with propionylating reagents $\left(\mathrm{DFRC}^{\prime}\right)$, it is possible to 
Table 3. Assignments of the Lignin ${ }^{13} \mathrm{C}-{ }^{1} \mathrm{H}$ Correlation Signals in the 2D HSQC Spectra of the MWL Isolated from Coconut Coir

\begin{tabular}{|c|c|c|}
\hline label & $\delta_{\mathrm{C}} / \delta_{\mathrm{H}}$ & assignment \\
\hline $\mathrm{B}_{\beta}$ & $53.1 / 3.45$ & $\begin{array}{l}\mathrm{C}_{\beta}-\mathrm{H}_{\beta} \text { in phenylcoumaran substructures } \\
\text { (B) }\end{array}$ \\
\hline $\mathrm{C}_{\beta}$ & $53.5 / 3.06$ & $\mathrm{C}_{\beta}-\mathrm{H}_{\beta}$ in $\beta-\beta^{\prime}$ resinol substructures (C) \\
\hline $\mathrm{OCH}_{3}$ & $55.5 / 3.74$ & $\mathrm{C}-\mathrm{H}$ in methoxyls \\
\hline $\mathrm{A}_{\gamma}$ & $59.8 / 3.24$ and 3.61 & $\begin{array}{l}\mathrm{C}_{\gamma}-\mathrm{H}_{\gamma} \text { in } \gamma \text {-hydroxylated } \beta-\mathrm{O}-4^{\prime} \\
\text { substructures }(\mathrm{A})\end{array}$ \\
\hline $\mathrm{I}_{\gamma}$ & $61.4 / 4.09$ & $\mathrm{C}_{\gamma}-\mathrm{H}_{\gamma}$ in cinnamyl alcohol end-groups \\
\hline $\mathrm{B}_{\gamma}$ & $62.6 / 3.71$ & $\begin{array}{l}\mathrm{C}_{\gamma}-\mathrm{H}_{\gamma} \text { in phenylcoumaran substructures } \\
\text { (B) }\end{array}$ \\
\hline $\mathrm{A}_{\gamma}^{\prime}$ & $63.3 / 4.46$ and 4.30 & $\begin{array}{l}\mathrm{C}_{\gamma}-\mathrm{H}_{\gamma} \text { in } \gamma \text {-acylated } \beta-\mathrm{O}-4^{\prime} \\
\text { substructures }\left(\mathrm{A}^{\prime}\right)\end{array}$ \\
\hline $\mathrm{A}_{\alpha(\mathrm{G})}$ & $71.0 / 4.75$ & $\begin{array}{l}\mathrm{C}_{\alpha}-\mathrm{H}_{\alpha} \text { in } \beta-\mathrm{O}-4^{\prime} \text { substructures }(\mathrm{A}) \\
\text { linked to a } \mathrm{G} \text { unit }\end{array}$ \\
\hline $\mathrm{C}_{\gamma}$ & $71.0 / 3.82$ and 4.18 & $\mathrm{C}_{\gamma}-\mathrm{H}_{\gamma}$ in $\beta-\beta^{\prime}$ resinol substructures (C) \\
\hline $\mathrm{A}_{\alpha(\mathrm{S})}$ & $71.7 / 4.87$ & $\begin{array}{l}\mathrm{C}_{\alpha}-\mathrm{H}_{\alpha} \text { in } \beta-\mathrm{O}-4^{\prime} \text { substructures }(\mathrm{A}) \\
\text { linked to a } \mathrm{S} \text { unit }\end{array}$ \\
\hline $\mathrm{A}_{\beta(\mathrm{H})}$ & $83.3 / 4.48$ & $\begin{array}{l}\mathrm{C}_{\beta}-\mathrm{H}_{\beta} \text { in } \beta-\mathrm{O}-4^{\prime} \text { substructures }(\mathrm{A}) \\
\text { linked to a } \mathrm{H} \text { unit }\end{array}$ \\
\hline $\mathrm{D}_{\alpha}$ & $83.2 / 4.84$ & $\begin{array}{l}\mathrm{C}_{\alpha}-\mathrm{H}_{\alpha} \text { in dibenzodioxocin substructures } \\
\text { (D) }\end{array}$ \\
\hline $\mathrm{A}_{\beta(\mathrm{G})}$ & $83.9 / 4.28$ & $\begin{array}{l}\mathrm{C}_{\beta}-\mathrm{H}_{\beta} \text { in } \beta-\mathrm{O}-4^{\prime} \text { substructures }(\mathrm{A}) \\
\text { linked to a } \mathrm{G} \text { unit }\end{array}$ \\
\hline $\mathrm{C}_{\alpha}$ & $84.9 / 4.67$ & $\mathrm{C}_{\alpha}-\mathrm{H}_{\alpha}$ in $\beta-\beta^{\prime}$ resinol substructures $(\mathrm{C})$ \\
\hline $\mathrm{D}_{\beta}$ & $85.4 / 3.87$ & $\begin{array}{l}\mathrm{C}_{\beta}-\mathrm{H}_{\beta} \text { in dibenzodioxocin substructures } \\
\text { (D) }\end{array}$ \\
\hline $\mathrm{A}_{\beta(\mathrm{s})}$ & $85.9 / 4.12$ & $\begin{array}{l}\mathrm{C}_{\beta}-\mathrm{H}_{\beta} \text { in } \beta-\mathrm{O}-4^{\prime} \text { substructures linked } \\
\text { (A) to a S unit }\end{array}$ \\
\hline $\mathrm{B}_{\alpha}$ & $86.8 / 5.46$ & $\begin{array}{l}\mathrm{C}_{\alpha}-\mathrm{H}_{\alpha} \text { in phenylcoumaran substructures } \\
\text { (B) }\end{array}$ \\
\hline $\mathrm{T}_{8}$ & $94.1 / 6.56$ & $\mathrm{C}_{8}-\mathrm{H}_{8}$ in tricin $(\mathrm{T})$ \\
\hline $\mathrm{T}_{6}$ & $98.8 / 6.20$ & $\mathrm{C}_{6}-\mathrm{H}_{6}$ in tricin $(\mathrm{T})$ \\
\hline$S_{2,6}$ & $103.9 / 6.71$ & $\mathrm{C}_{2}-\mathrm{H}_{2}$ and $\mathrm{C}_{6}-\mathrm{H}_{6}$ in $\mathrm{S}$ units \\
\hline $\mathrm{G}_{2}$ & $110.9 / 7.00$ & $\mathrm{C}_{2}-\mathrm{H}_{2}$ in $\mathrm{G}$ units \\
\hline $\mathrm{I}_{2}$ & $112.4 / 7.31$ & $\begin{array}{l}\mathrm{C}_{2}-\mathrm{H}_{2} \text { in cinnamaldehyde end-groups } \\
\text { (I) }\end{array}$ \\
\hline $\mathrm{PB}_{3,5}$ & $114.3 / 6.61$ & $\begin{array}{l}\mathrm{C}_{3}-\mathrm{H}_{3} \text { and } \mathrm{C}_{5}-\mathrm{H}_{5} \text { in } p \text {-hydroxybenzoate } \\
\quad \text { (PB) }\end{array}$ \\
\hline $\mathrm{H}_{3,5}$ & $114.9 / 6.76$ & $\mathrm{C}_{3,5}-\mathrm{H}_{3,5}$ in $\mathrm{H}$ units \\
\hline $\mathrm{G}_{5} / \mathrm{G}_{6}$ & $\begin{array}{l}115.0 / 6.74 \text { and } 6.94 \\
118.8 / 6.79\end{array}$ & $\mathrm{C}_{5}-\mathrm{H}_{5}$ and $\mathrm{C}_{6}-\mathrm{H}_{6}$ in $\mathrm{G}$ units \\
\hline $\mathrm{I}_{6}$ & $118.7 / 7.31$ & $\begin{array}{l}\mathrm{C}_{6}-\mathrm{H}_{6} \text { in cinnamaldehyde end-groups } \\
\text { (I) }\end{array}$ \\
\hline $\mathrm{I}_{\beta}$ & $126.3 / 6.76$ & $\begin{array}{l}\mathrm{C}_{\beta}-\mathrm{H}_{\beta} \text { in cinnamaldehyde end-groups } \\
\text { (I) }\end{array}$ \\
\hline $\mathrm{H}_{2,6}$ & $127.8 / 7.20$ & $\mathrm{C}_{2,6}-\mathrm{H}_{2,6}$ in $\mathrm{H}$ units \\
\hline $\mathrm{E}_{\beta}$ & $129.0 / 6.23$ & $\begin{array}{l}\mathrm{C}_{\beta}-\mathrm{H}_{\beta} \text { in cinnamyl alcohol end-groups } \\
\text { (E) }\end{array}$ \\
\hline $\mathrm{E}_{\alpha}$ & $129.0 / 6.45$ & $\begin{array}{l}\mathrm{C}_{\alpha}-\mathrm{H}_{\alpha} \text { in cinnamyl alcohol end-groups } \\
\text { (E) }\end{array}$ \\
\hline $\mathrm{PB}_{2,6}$ & $131.2 / 7.68$ & $\begin{array}{l}\mathrm{C}_{2}-\mathrm{H}_{2} \text { and } \mathrm{C}_{6}-\mathrm{H}_{6} \text { in } p \text {-hydroxybenzoate } \\
\text { (PB) }\end{array}$ \\
\hline $\mathrm{I}_{\alpha}$ & $153.5 / 7.60$ & $\begin{array}{l}\mathrm{C}_{\alpha}-\mathrm{H}_{\alpha} \text { in cinnamaldehyde end-groups } \\
\text { (I) }\end{array}$ \\
\hline
\end{tabular}

obtain information about the occurrence and extent of native lignin acetylation. ${ }^{39,51}$

Figure 4 shows the chromatogram of the DFRC' products released from the MWL from coconut coir. The DFRC' released the cis- and trans-isomers of $\mathrm{H}-(c \mathrm{H}$ and $t \mathrm{H}), \mathrm{G}-(c \mathrm{G}$ and $t G)$, and S-type ( $c S$ and $t S$ ) lignin monomers, as their propionylated derivatives, arising from normal $\gamma-\mathrm{OH}$ units in lignin. In addition, the presence of $\gamma$-acetylated $\mathrm{G}$ ( $c \mathrm{Gac}$ and $t \mathrm{Gac}$ ) and $S(c S a c$ and $t \mathrm{Sac})$ lignin units, arising from originally
Table 4. Structural Characteristics (lignin interunit linkages, cinnamyl end-groups, percentage of $\gamma$-acylation, aromatic units and $S / G$ ratio, and $p$-hydroxybenzoate content) from Integration of ${ }^{13} \mathrm{C}-{ }^{1} \mathrm{H}$ Correlation Signals in the HSQC Spectra of the MWL Isolated from Coconut Coir

$\begin{array}{cc}\text { lignin interunit linkages (\%) } & \\ \beta-\mathrm{O}-4^{\prime} \text { aryl ethers (A/A') } & 82 \\ \text { phenylcoumarans (B) } & 13 \\ \text { resinols (C) } & 4 \\ \text { dibenzodioxocins (D) }^{a} & 1 \\ \text { lignin end-groups } & \\ \text { cinnamyl alcohol end-groups (E) }^{\prime} & 5 \\ \text { cinnamaldehyde end-groups (I) }^{\prime} & 15 \\ \text { lignin side chain } \gamma \text {-acylation (\%) } & 11 \\ \text { lignin aromatic units } & \\ \text { H (\%) } & 4 \\ \text { G (\%) } & 78 \\ \text { S (\%) } & 18 \\ \text { H/G ratio } & 0.0 \\ \text { S/G ratio } & 0.23 \\ p \text {-hydroxybenzoates } & \end{array}$

${ }^{a}$ Expressed as a fraction of the total lignin interunit linkage types A-D. ${ }^{b}$ Molar percentages $(\mathrm{H}+\mathrm{G}+\mathrm{S}=100) .{ }^{c} p$-Hydroxybenzoate molar content as percentage of lignin content $(H+G+S)$.

acetylated lignin units, could also be observed in the chromatogram, indicating that some $\gamma$-acetylation occurred on the lignin side chain. The DFRC' analyses indicated a low extent of acetylation, preferentially on S-monomers (6\%), whereas only $1 \%$ of G-monomers were $\gamma$-acetylated.

Thioacidolysis. The MWL from coconut coir was also analyzed by thioacidolysis. The composition of the lignin monomers released after thioacidolysis showed a predominance of $G$ over $S$ units and smaller amounts of $H$ units, with a $H: G: S$ composition of 7:68:25 (Table 5). As expected, the molar S/G ratio obtained (0.37) is higher than those estimated from PyGC/MS (0.29) and NMR (0.23), because $S$ units are mostly involved in alkyl aryl ether linkages $\left(\beta-O-4^{\prime}\right.$ and $\left.\alpha-O-4^{\prime}\right)$, which are the ones cleaved during thioacidolysis. ${ }^{10,33-35}$

The dimers recovered after thioacidolysis can provide useful information about the different units involved in the various carbon-carbon and diaryl ether linkages, ${ }^{34,35}$ often referred to as the "condensed" bonds (including 5-5', 4-O-5', $\beta-1$ ', $\beta-$ $5^{\prime}$, and $\left.\beta-\beta^{\prime}\right)$. To study lignin dimers, the thioacidolysis degradation products were subjected to a Raney nickel desulfurization, and the products obtained were analyzed by GC-MS. The chromatograms of the trimethylsilylated thioacidolysis degradation products are shown in Figure 5. The released compounds were identified according to previously reported mass spectra. ${ }^{21,24,35,41-43}$ The structures of the main compounds identified are shown in Figure 6, and their relative molar abundances are summarized in Table 6 . The dimers identified were 5-5' (dimers 1-4, 6, and 8), 4-O-5' (dimers 5 , 9, and 12), $\beta-1^{\prime}$ (dimers $7,10,13,16$, and 18), $\beta-5^{\prime}$ (dimers 11, 14, 15, 17, 19, and 24), and $\beta-\beta^{\prime}$ tetralin (dimers 20-23 and 25) types. The relative molar abundances of the different types of condensed dimers released from the MWL of coconut coir are shown in Table 7.

Dimeric compounds with $\beta-5^{\prime}$ structures, arising from opening the $\alpha-\mathrm{O}-4^{\prime}$ ethers in phenylcoumaran substructures, were the most prominent thioacidolysis dimers released from the lignin of coconut coir, accounting for $45.8 \%$ of the total 

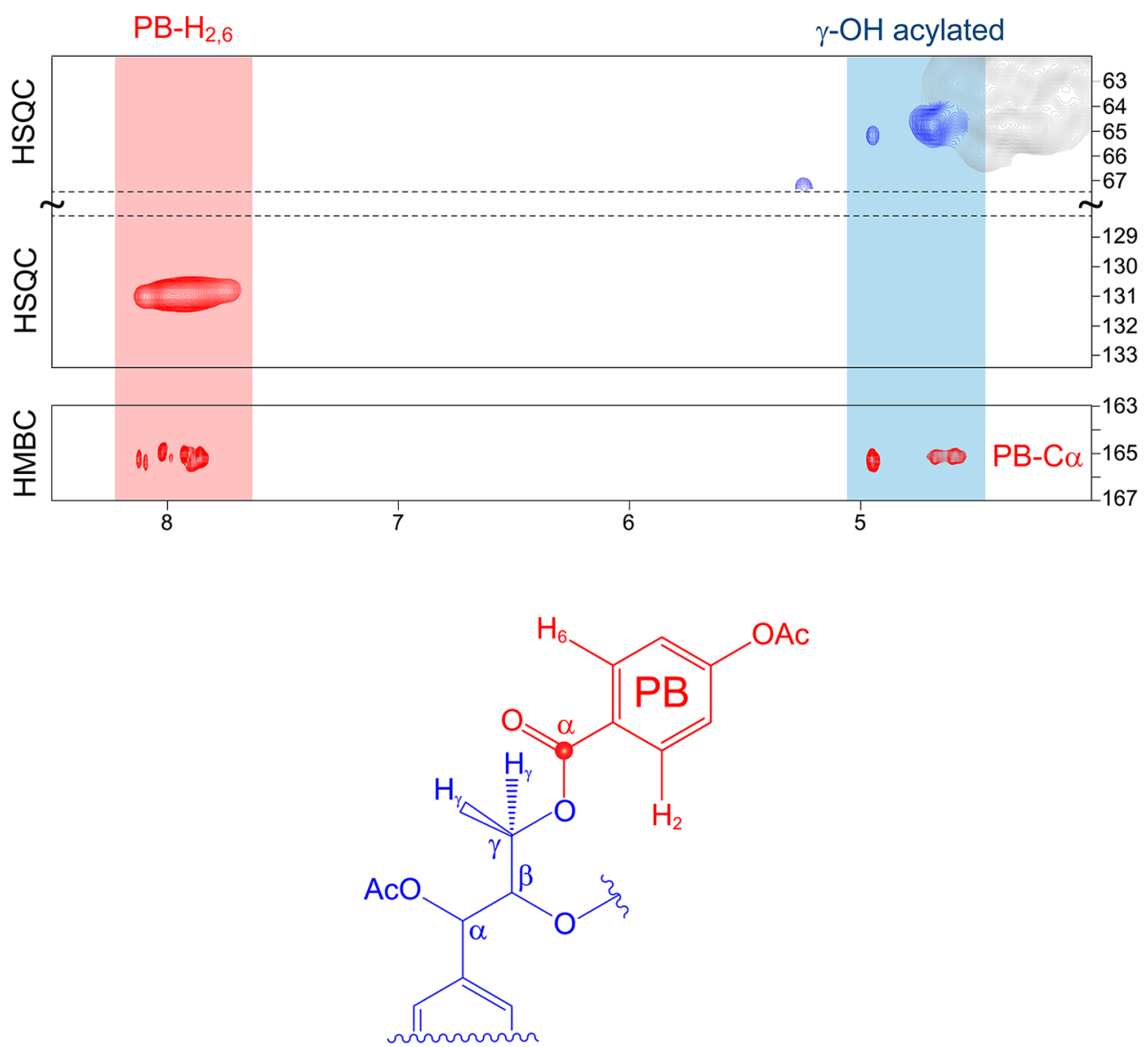

Figure 3. Section of the HMBC spectrum $\left(\delta_{\mathrm{C}} / \delta_{\mathrm{H}} 163-167 / 4.0-8.5\right)$ of acetylated coconut coir MWL (in $\left.\mathrm{CDCl}_{3}\right)$ showing the main correlations for the carbonyl carbon of the $p$-hydroxybenzoates acylating the $\gamma$-positions of the lignin side chains. Appropriate sections of the HSQC spectrum showing the $\mathrm{C}_{\gamma}-\mathrm{H}_{\gamma}$ correlations of the acylated lignin $\gamma$-carbon $\left(\delta_{\mathrm{C}} 62-68\right)$ and the $\mathrm{C}_{2,6}-\mathrm{H}_{2,6}$ correlations of $p$-hydroxybenzoates $\left(\delta_{\mathrm{C}} 128-133\right)$ are also depicted.

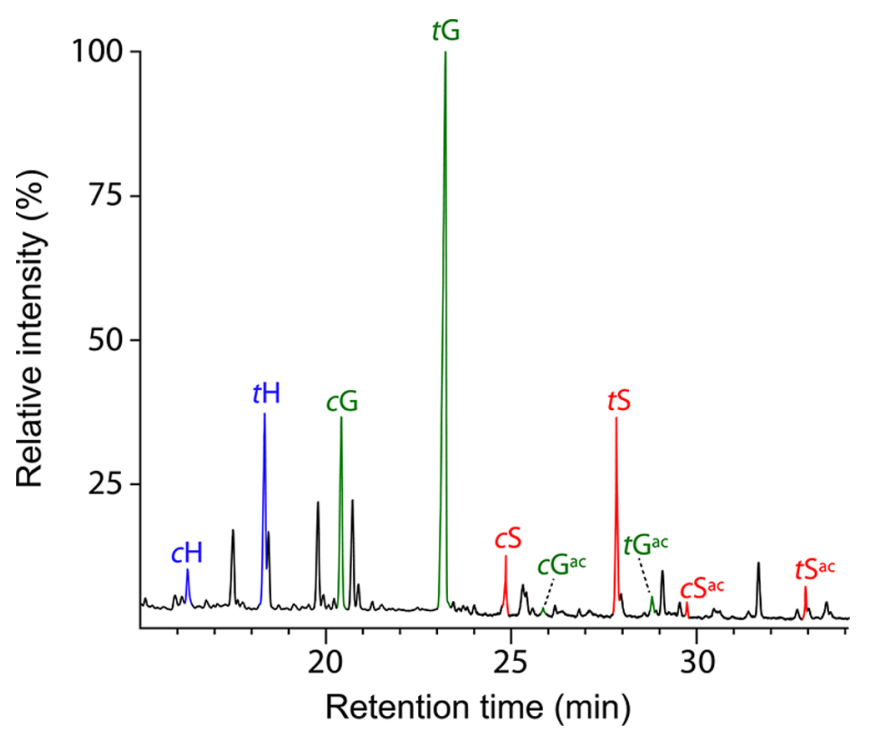

Figure 4. Total-ion chromatogram (TIC) from GC/MS of the DFRC' degradation products from the $\mathrm{MWL}$ isolated from coconut coir. $c \mathrm{H}$, $t \mathrm{H}, c \mathrm{G}, t \mathrm{G}, c \mathrm{~S}$, and $t \mathrm{~S}$ are the normal cis- and trans-p-hydroxyphenyl, -coniferyl, and -sinapyl alcohols (as their dipropionylated derivatives). $c \mathrm{Gac}, t \mathrm{Gac}, c \mathrm{Sac}$, and $t \mathrm{Sac}$ are the natively $\gamma$-acetylated cis- and transconiferyl and -sinapyl alcohols (as their phenol-propionylated derivatives).
Table 5. Yields of the Monomers ( $\mu \mathrm{mol} / \mathrm{g}$ lignin) Released after Thioacidolysis

$\begin{array}{lc}\text { monomers } & \text { yields }(\mu \mathrm{mol} / \mathrm{g} \text { lignin }) \\ \mathrm{H} & 62 \\ \mathrm{G} & 594 \\ \mathrm{~S} & 218 \\ \text { total } & 874 \\ \mathrm{H} / \mathrm{G} \text { ratio } & 0.10 \\ \mathrm{~S} / \mathrm{G} \text { ratio } & 0.37\end{array}$

identified dimers. The most important dimeric $\beta-5^{\prime}$ structures (15 and 17) were composed of two G units, whereas GH (11 and 14) and SG (19 and 24) dimers were released in smaller amounts. These data are in agreement with the $2 \mathrm{D}$ NMR spectrum shown above that indicates that phenylcoumaran structures are the most important condensed structures in coir lignin.

Dimeric $\beta-1^{\prime}$ structures were also observed among the thioacidolysis dimers in coconut coir lignin. The existence of $\beta-1^{\prime}$ dimeric substructures in lignin has been a matter of controversy. Two $\beta-1^{\prime}$-linked substructures, spirodienones, and phenylisochromans, were identified using 2D NMR in combination with DFRC. ${ }^{55,56}$ Phenylisochromans are resistant toward thioacidolysis; therefore, only spirodienones or opened forms of the $\beta-1^{\prime}$ units could be at the origin of the $\beta-1^{\prime}$ dimers observed here. ${ }^{21}$ In the MWL of coconut coir, $\beta-1^{\prime}$ 


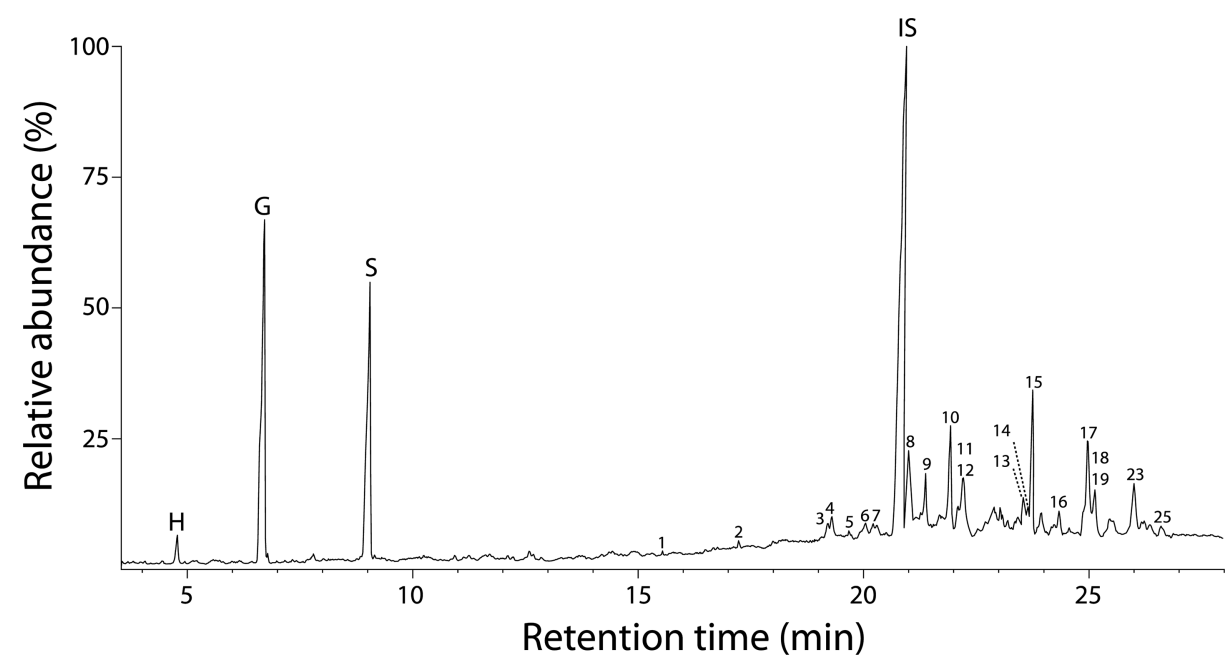

Figure 5. Chromatogram (GC-TIC) of the thioacidolysis degradation products (after Raney nickel desulfurization) released from coconut coir MWL, as trimethylsilyl derivatives. The numbers refer to the dimeric compounds listed in Table 6; the structures are shown in Figure 6.<smiles>[R]CCc1cc([R])c(O)c(-c2cc(CC[R])cc([R])c2O)c1</smiles>

$1(H H) R_{1}=R_{2}=R_{3}=R_{4}=H$ $2(\mathrm{HG}) \mathrm{R}_{1}=\mathrm{R}_{2}=\mathrm{R}_{4}=\mathrm{H}, \mathrm{R}_{2}=\mathrm{OCH}_{3}$ $3(\mathrm{GG}) \mathrm{R}_{1}=\mathrm{R}_{2}=\mathrm{OCH}_{3}, \mathrm{R}_{3}=\mathrm{R}_{4}=\mathrm{H}$ $4(\mathrm{HG}) \mathrm{R}_{1}=\mathrm{H}, \mathrm{R}_{2}=\mathrm{OCH}_{3}, \mathrm{R}_{3}=\mathrm{R}_{4}=\mathrm{CH}_{3}$ $6(\mathrm{GG}) \mathrm{R}_{1}=\mathrm{R}_{2}=\mathrm{OCH}_{3}, \mathrm{R}_{3}=\mathrm{H}, \mathrm{R}_{4}=\mathrm{CH}_{3}$ 8 (GG) $\mathrm{R}_{1}=\mathrm{R}_{2}=\mathrm{OCH}_{3}, \mathrm{R}_{3}=\mathrm{R}_{4}=\mathrm{CH}_{3}$

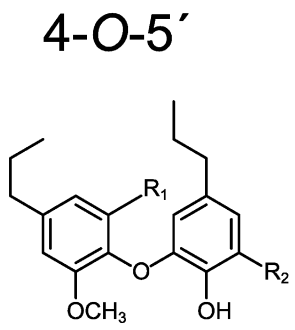

$5(\mathrm{GH}) \mathrm{R}_{1}=\mathrm{R}_{2}=\mathrm{H}$

9 (GG) $\mathrm{R}_{1}=\mathrm{H}, \mathrm{R}_{2}=\mathrm{OCH}_{3}$ 12 (SG) $\mathrm{R}_{1}=\mathrm{R}_{2}=\mathrm{OCH}_{3}$<smiles>[R]c1cc(CC([R])c2cc([R])c(O)c([R])c2)cc([R])c1O</smiles>

$7(\mathrm{GH}) \mathrm{R}_{1}=\mathrm{R}_{3}=\mathrm{R}_{4}=\mathrm{R}_{5}=\mathrm{H}, \mathrm{R}_{2}=\mathrm{OCH}_{3}$ 10 (GG) $R_{1}=R_{3}=R_{5}=H, R_{2}=R_{4}=\mathrm{OCH}_{3}$ 13 (SG) $\mathrm{R}_{3}=\mathrm{R}_{5}=\mathrm{H}, \mathrm{R}_{1}=\mathrm{R}_{2}=\mathrm{R}_{4}=\mathrm{OCH}_{3}$ 16 (GG) $R_{1}=R_{3}=H, R_{2}=R_{4}=\mathrm{OCH}_{3}, R_{5}=\mathrm{CH}_{2} \mathrm{O}$

18 (SS) $\mathrm{R}_{1}=\mathrm{R}_{2}=\mathrm{R}_{3}=\mathrm{R}_{4}=\mathrm{OCH}_{3}, \mathrm{R}_{5}=\mathrm{CH}_{2} \mathrm{OH}$<smiles>[R]CCc1cc([R9])c(O)c(C([R])Cc2cc([R])c(O)c([R])c2)c1</smiles>

$11(\mathrm{GH}) \mathrm{R}_{1}=\mathrm{R}_{3}=\mathrm{R}_{4}=\mathrm{H}, \mathrm{R}_{2}=\mathrm{OCH}_{3}, \mathrm{R}_{5}=\mathrm{CH}_{3}$ $14(\mathrm{GH}) \mathrm{R}_{1}=\mathrm{R}_{3}=\mathrm{H}, \mathrm{R}_{2}=\mathrm{OCH}_{3}, \mathrm{R}_{4}=\mathrm{CH}_{2} \mathrm{OH}, \mathrm{R}_{5}=\mathrm{CH}_{3}$ 15 (GG) $\mathrm{R}_{1}=\mathrm{H}, \mathrm{R}_{2}=\mathrm{R}_{3}=\mathrm{OCH}_{3}, \mathrm{R}_{4}=\mathrm{H}, \mathrm{R}_{5}=\mathrm{CH}_{3}$ $17(G G) R_{1}=H, R_{2}=R_{3}=\mathrm{OCH}_{3}, \mathrm{R}_{4}=\mathrm{CH}_{2} \mathrm{OH}, \mathrm{R}_{5}=\mathrm{CH}_{3}$ 19 (SG) $\mathrm{R}_{1}=\mathrm{R}_{2}=\mathrm{R}_{3}=\mathrm{OCH}_{3}, \mathrm{R}_{4}=\mathrm{H}, \mathrm{R}_{5}=\mathrm{CH}_{3}$

24 (SG) $\mathrm{R}_{1}=\mathrm{R}_{2}=\mathrm{R}_{3}=\mathrm{OCH}_{3}, \mathrm{R}_{4}=\mathrm{CH}_{2} \mathrm{OH}, \mathrm{R}_{5}=\mathrm{CH}_{3}$

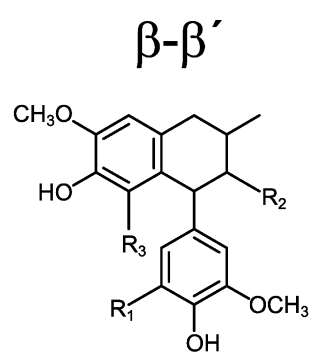

20 (SS) $\mathrm{R}_{1}=\mathrm{R}_{3}=\mathrm{OCH}_{3}, \mathrm{R}_{2}=\mathrm{H}$ 22 (SG) $\mathrm{R}_{1}=\mathrm{OCH}_{3}, \mathrm{R}_{2}=\mathrm{CH}_{3}, \mathrm{R}_{3}=\mathrm{H}$

21, 23, 25 (SS) $\mathrm{R}_{1}=\mathrm{OCH}_{3}, \mathrm{R}_{2}=\mathrm{CH}_{3}, \mathrm{R}_{2}=\mathrm{OCH}_{3}$

Figure 6. Structures of dimeric compounds obtained after thioacidolysis and Raney nickel desulfurization of the MWL isolated from coconut coir.

dimers represent the second most abundant dimers $(22.1 \%$ of all dimeric structures). However, the relatively large amounts of $\beta-1^{\prime}$ dimers observed upon thioacidolysis are not in agreement with the NMR spectra shown above, which indicated the 
Table 6. Identification and Relative Molar Abundances of the Dimers Released after Thioacidolysis and Raney Nickel Desulfurization of the MWL from Coconut Coir ${ }^{a}$

\begin{tabular}{|c|c|c|c|}
\hline compd & linkage & MW & rel abundance (\%) \\
\hline 1 & $5-5^{\prime}(\mathrm{HH})$ & 386 & 0.1 \\
\hline 2 & $5-5^{\prime}(\mathrm{HG})$ & 416 & 0.4 \\
\hline 3 & $5-5^{\prime}(\mathrm{GG})$ & 446 & 1.4 \\
\hline 4 & $5-5^{\prime}(\mathrm{HG})$ & 444 & 2.0 \\
\hline 5 & $4-\mathrm{O}-5^{\prime}(\mathrm{GH})$ & 372 & 0.4 \\
\hline 6 & $5-5^{\prime}(\mathrm{GG})$ & 460 & 1.5 \\
\hline 7 & $\beta-1^{\prime}(\mathrm{GH})$ & 388 & 1.9 \\
\hline 8 & $5-5^{\prime}(\mathrm{GG})$ & 474 & 10.6 \\
\hline 9 & $4-\mathrm{O}-5^{\prime}$ (GG) & 402 & 5.4 \\
\hline 10 & $\beta-1^{\prime}(\mathrm{GG})$ & 418 & 13.6 \\
\hline 11 & $\beta-5^{\prime}(\mathrm{GH})$ & 430 & 3.5 \\
\hline 12 & $4-\mathrm{O}-5^{\prime}(\mathrm{SG})$ & 432 & 1.7 \\
\hline 13 & $\beta-1^{\prime}(\mathrm{SG})$ & 448 & 3.1 \\
\hline 14 & $\beta-5^{\prime}(\mathrm{GH})$ & 532 & 1.3 \\
\hline 15 & $\beta-5^{\prime}(\mathrm{GG})$ & 460 & 24.5 \\
\hline 16 & $\beta-1^{\prime}(\mathrm{GG})$ & 520 & 1.8 \\
\hline 17 & $\beta-5^{\prime}(\mathrm{GG})$ & 562 & 12.2 \\
\hline 18 & $\beta-1^{\prime}(\mathrm{SS})$ & 478 & 1.7 \\
\hline 19 & $\beta-5^{\prime}(\mathrm{SG})$ & 490 & 4.3 \\
\hline 20 & $\beta-\beta^{\prime}(\mathrm{SS})$ & 518 & 0.6 \\
\hline 21 & $\beta-\beta^{\prime}$ (SS) & 532 & 0.2 \\
\hline 22 & $\beta-\beta^{\prime}(\mathrm{SG})$ & 502 & 0.7 \\
\hline 23 & $\beta-\beta^{\prime}(\mathrm{SS})$ & 532 & 6.1 \\
\hline 24 & $\beta-5^{\prime}(\mathrm{SG})$ & 592 & 0.2 \\
\hline 25 & $\beta-\beta^{\prime}(\mathrm{SS})$ & 532 & 1.0 \\
\hline
\end{tabular}

${ }^{a}$ The structures are depicted in Figure 6.

Table 7. Relative Molar Percentages of the Different Dimer Types (see Table 6 and Figure 6) Released after Thioacidolysis and Raney Nickel Desulfurization of Coconut Coir MWL

\begin{tabular}{cccc} 
linkage type & units involved & percentage & total \\
$5-5^{\prime}$ & HH & 0.1 & 15.9 \\
& HG & 2.4 & \\
$4-\mathrm{O}-5^{\prime}$ & $\mathrm{GG}$ & 13.4 & 7.4 \\
& $\mathrm{HG}$ & 0.4 & \\
$\beta-1^{\prime}$ & $\mathrm{GG}$ & 5.4 & \\
& $\mathrm{GS}$ & 1.7 & 22.1 \\
& $\mathrm{HG}$ & 1.9 & \\
& $\mathrm{GG}$ & 15.5 & \\
& $\mathrm{GS}$ & 3.1 & 45.8 \\
$\beta-5^{\prime}$ & $\mathrm{SS}$ & 1.7 & \\
& $\mathrm{HG}$ & 4.7 & \\
& $\mathrm{GG}$ & 36.6 & \\
& $\mathrm{GS}$ & 4.5 & \\
& $\mathrm{GS}$ & 0.7 & \\
& $\mathrm{SS}$ & 8.0 & \\
\hline
\end{tabular}

absence (or the occurrence below the detection level of the NMR technique) of spirodienones in coir lignin. The apparent thioacidolysis dimer anomaly is largely explained by the difficulty of releasing other dimers that are therefore produced in low yields, and the special nature of the $\beta-1^{\prime}$-units, the spirodienones, which are etherified only at one 'end' as dictated by their mode of formation; ${ }^{10}$ their release is therefore disproportionately high. As occurs with the $\beta-5^{\prime}$ structures, the most significant $\beta-1^{\prime}$ dimeric structure $(10$, but also 16$)$ was composed of two $G$ units, whereas other $\beta-1^{\prime}$ dimeric structures, the GH (11), SG (13), and SS (18) dimers, were present in smaller amounts.

Dimers of $5-5^{\prime}$ biphenyl structure were the third most abundant dimeric compounds in these lignin samples, accounting for $15.9 \%$ of all dimeric compounds. Dimers composed of two $\mathrm{G}$ units $(3,6,8)$ were the most abundant, with smaller amounts of $\mathrm{HH}(1)$ and HG $(2,4) 5-5^{\prime}$ dimeric structures. Dibenzodioxocins are considered to be the main biphenyl structures in lignin; ${ }^{57}$ therefore, the $5-5^{\prime}$ thioacidolysis dimers can be considered mostly as being dibenzodioxocin degradation products, although simple biphenyl structures have also been reported in lignin; ${ }^{27}$ how readily dibenzodioxocins release 5-5-dimers upon thioacidolysis has not yet been well documented.

The remainder of the thioacidolysis dimeric compounds, such as $\beta-\beta^{\prime}$ and $4-\mathrm{O}-5^{\prime}$ dimers, was present in smaller amounts. Among these, it is interesting to note the low proportion of $\beta-\beta^{\prime}$ dimers observed after thioacidolysis $(8.7 \%$ of total dimeric structures) compared to $\beta-1^{\prime}$ dimers that contrast with the relatively large amounts of $\beta-\beta^{\prime}$ resinol-type structures observed in the HSQC spectra (4\% of all interunit linkages). This fact may indicate that $\beta-\beta^{\prime}$ resinol-type structures, particularly those with guaiacyl units, could be linked via other condensed bonds and, therefore, after thioacidolysis, they will form trimers or higher oligomers that cannot be detected. Thioacidolysis trimeric compounds formed by $\beta-\beta^{\prime}$ tetralin dimers linked by a $4-\mathrm{O}-5^{\prime}$ ether bond to a $\mathrm{G}$ lignin unit have been identified in the lignins of many plants, including herbaceous, ${ }^{42}$ hardwoods, ${ }^{21,38}$ and softwoods. ${ }^{59}$ Nearly all $(92 \%)$ the $\beta-\beta^{\prime}$ dimers released from coir lignin upon thioacidolysis were of the syringaresinol type (pinoresinol being absent and the G-S structure appearing only as a minor substructure) (Table 7). This is much more than expected from random coupling in a monolignol mixture with $\sim 4$-fold higher concentration of coniferyl alcohol than sinapyl alcohol (as indicated by the $S / G$ ratio of this lignin). The almost exclusive occurrence in coir lignin of $\beta-\beta^{\prime}$ dimeric structures from syringaresinol, together with the lack of pinoresinol-derived structures, was also observed in the lignins of other angiosperms, such as eucalypt ${ }^{21}$ and jute; ${ }^{42}$ however, this is the first time that the almost exclusive occurrence of syringaresinol has been found to occur in a lignin highly depleted in S-units.

A Comment on Lignin Attributes and Plant Phylogeny. Although the aim of this paper is not on plant phylogeny, nor on chemotaxonomy, there are some potentially interesting observations regarding the coir's lignin structural units relating to coconut's place in the Arecales order, and the Arecaceae (palm) family in the monocot class of plant phylogeny. As noted above, we find rather complelling evidence that the flavone tricin is incorporated into the coconut coir lignin, as we have noted recently in various grasses (Poales order, Poaceae family). ${ }^{12}$ However, unlike in grasses, there is no significant $p$ coumarate component acylating the lignin. Like its palm (Arecales order, Arecaceae or Palmae family) relatives (but as also noted in angiosperm/dicot lines, Salix and Populus, both in the Salicaceae family), and unlike in grasses, the lignins are acylated by $p$-hydroxybenzoate. ${ }^{18,19,32,45-49}$ Other groups are currently examining $p$-coumarate involvement across various monocots; ${ }^{60}$ we suggest that tracking the distribution of tricin and delineating the $p$-coumarate vs $p$-hydroxybenzoate distribution may also prove interesting. 
In conclusion, we have performed the first detailed structural characterization of the abundant lignin in coconut coir. The study, by a range of powerful analytical methods, indicated that it is an $\mathrm{H}: \mathrm{G}: \mathrm{S}$ lignin with a strong predominance of G-lignin units (S/G 0.23). Two-dimensional NMR indicated that the main linkages present in this lignin are $\beta-\mathrm{O}-4^{\prime}$ alkyl aryl ethers, followed by phenylcoumarans, resinols, and small amounts of dibenzodioxocins, together with cinnamyl alcohol and cinnamaldehyde end-groups. Two-dimensional NMR also indicated that the lignin of coconut coir is partially acylated ( $11 \%$ of all side chains), and exclusively at the $\gamma-\mathrm{OH}$ of the side chain, with $p$-hydroxybenzoates. DFRC analyses indicated that the $\gamma$-carbon is additionally acylated with acetates, although to a lower extent. Despite coir lignins being highly enriched in $\mathrm{G}$-units, thioacidolysis degradation indicated that $\beta-\beta^{\prime}$ resinol structures are mostly of the syringaresinol type, pinoresinol units being completely absent. Finally, the tricin units recently identified in grass lignins are also present, at a fairly low level here, suggesting that they might be a feature of monocot lignins. These data, highlighting the similarities and differences between coir lignin and lignins from other biomass sources, will help to optimize the use of this coir resource for products and biomaterials.

\section{AUTHOR INFORMATION}

\section{Corresponding Author}

*Tel: +34-95-4624711; fax: +34-95-4624002; e-mail: jrencoret@irnase.csic.es.

\section{Funding}

This study has been funded by the Spanish project AGL201125379 , the CSIC project 201040E075, and the EU-project LIGNODECO (KBBE-244362). Dr. Jorge Rencoret thanks the CSIC for a JAE-DOC contract of the program "Junta para la Ampliación de Estudios” cofinanced by Fondo Social Europeo (FSE). John Ralph was funded by the DOE Great Lakes Bioenergy Research Center (DOE Office of Science BER DEFC02-07ER64494).

\section{Notes}

The authors declare no competing financial interest.

\section{ACKNOWLEDGMENTS}

We thank José M. Gras and Gerardo Artal (CELESA, Spain) for providing the coconut coir. Yuki Tobimatsu (Univ. Wisconsin, Madison) is acknowledged for performing the GPC analyses, and Fachuang $\mathrm{Lu}$ and Hoon Kim (Univ. Wisconsin, Madison) for their valuable technical advice. We also thank Dr. Manuel Angulo (CITIUS, Universidad de Seville) for performing the NMR analyses.

\section{REFERENCES}

(1) Wang, W.; Huang, G. Characterisation and utilization of natural coconut fibres composites. Mater. Des. 2009, 30, 2741-2744.

(2) Kirby, R. H. Vegetable Fibers, Botany, Cultivation and Utilization; Leonard Hill Ltd: London, UK, 1963.

(3) Abdul Khalil, H. P. S.; Siti Alwani, M.; Mohd Omar, A. K. Chemical composition, anatomy, lignin distribution, and cell wall structure of Malaysian plant waste fibers. BioResources 2006, 1, 13.

(4) Malherbe, S.; Cloete, T. E. Lignocellulose biodegradation: Fundamentals and applications. Rev. Environ. Sci. Biotechnol. 2002, 1, 105-114.

(5) Ragauskas, A. J.; Williams, C. K.; Davison, B. H.; Britovsek, G.; Cairney, J.; Eckert, C. A.; Frederick, W. J.; Hallett, J. P.; Leak, D. J.; Liotta, C. L.; Mielenz, J. R.; Murphy, R.; Templer, R.; Tschaplinski, T.
The path forward for biofuels and biomaterials. Science 2006, 311, 484-489.

(6) Somerville, C.; Youngs, H.; Taylor, C.; Davis, S. C.; Long, S. P. Feedstocks for lignocellulosic biofuels. Science 2010, 329, 790-792.

(7) Sarkar, N.; Ghosh, S. K.; Bannerjee, S.; Aikat, K. Bioethanol production from agricultural wastes: An overview. Renew. Energy 2012, $37,19-27$.

(8) Simmons, B. A.; Loqué, D.; Ralph, J. Advances in modifying lignin for enhanced biofuel production. Curr. Opin. Plant Biol. 2010, $13,313-320$

(9) Abramson, M.; Shoseyov, O.; Shani, Z. Plant cell wall reconstruction toward improved lignocellulosic production and processability. Plant Sci. 2010, 178, 61-72.

(10) Ralph, J.; Lundquist, K.; Brunow, G.; Lu, F.; Kim, H.; Schatz, P. F.; Marita, J. M.; Hatfield, R. D.; Ralph, S. A.; Christensen, J. H.; Boerjan, W. Lignins: natural polymers from oxidative coupling of 4hydroxyphenylpropanoids. Phytochem. Rev. 2004, 3, 29-60.

(11) del Río, J. C.; Prinsen, P.; Rencoret, J.; Nieto, L.; JiménezBarbero, J.; Ralph, J.; Martínez, Á. T.; Gutiérrez, A. Structural characterization of the lignin in the cortex and pith of elephant grass (Pennisetum purpureum) Stems. J. Agric. Food Chem. 2012, 60, 36193634.

(12) del Río, J. C.; Rencoret, J.; Prinsen, P.; Martínez, Á. T.; Ralph, J.; Gutiérrez, A. Structural characterization of wheat straw lignin as revealed by analytical pyrolysis, $2 \mathrm{D}-\mathrm{NMR}$, and reductive cleavage methods. J. Agric. Food Chem. 2012, 60, 5922-5935.

(13) Björkman, A. Studies on finely divided wood. Part I. Extraction of lignin with neutral solvents. Sven. Papperstidn. 1956, 59, 477-485.

(14) Fujimoto, A.; Matsumoto, Y.; Chang, H. M.; Meshitsuka, G. Quantitative evaluation of milling effects on lignin structure during the isolation process of milled wood lignin. J. Wood Sci. 2005, 51, 89-91.

(15) del Río, J. C.; Gutiérrez, A.; Rodríguez, I. M.; Ibarra, D.; Martínez, Á. T. Composition of non-woody plant lignins and cinnamic acids by Py-GC/MS, Py/TMAH and FT-IR. J. Anal. Appl. Pyrol. 2007, 79, 39-46.

(16) Ralph, J.; Hatfield, R. D. Pyrolysis-GC-MS characterization of forage materials. J. Agric. Food Chem. 1991, 39, 1426-1437.

(17) Faix, O.; Meier, D.; Fortmann, I. Thermal degradation products of wood. Gas chromatographic separation and mass spectrometric characterization of monomeric lignin-derived products. Holz RohWerkst. 1990, 48, 281-289.

(18) Ralph, J. Hydroxycinnamates in Lignification. Phytochem. Revs. 2010, 9, 65-83.

(19) Kuroda, K.; Ozawa, T.; Ueno, T. Characterization of sago palm (Metroxylon sagu Rottb.) lignin by analytical pyrolysis. J. Agric. Food Chem. 2001, 49, 1840-1847.

(20) del Rio, J. C.; Martin, F.; Gonzalez-Vila, F. J. Thermally assisted hydrolysis and alkylation as a novel pyrolytic approach for the structural characterization of natural biopolymers and geomacromolecules. Trends Anal. Chem. 1996, 15, 70-79.

(21) Rencoret, J.; Marques, G.; Gutierrez, A.; Ibarra, D.; Li, J.; Gellerstedt, G.; Santos, J. I.; Jimenez-Barbero, J.; Martinez, A. T.; del Río, J. C. Structural characterization of milled wood lignins from different eucalypt species. Holzforschung 2008, 62, 514-526.

(22) Capanema, E. A.; Balakshin, M. Y.; Kadla, J. F. A comprehensive approach for quantitative lignin characterization by NMR spectroscopy. J. Agric. Food Chem. 2004, 52, 1850-1860.

(23) Capanema, E. A.; Balakshin, M. Y.; Kadla, J. F. Quantitative characterization of a hardwood milled wood lignin by nuclear magnetic resonance spectroscopy. J. Agric. Food Chem. 2005, 53, 9639-9649.

(24) Rencoret, J.; Gutiérrez, A.; Nieto, L.; Jiménez-Barbero, J.; Faulds, C. B.; Kim, H.; Ralph, J.; Martínez, Á. T.; del Río, J. C. Lignin composition and structure in young versus adult Eucalyptus globulus plants. Plant Physiol. 2011, 155, 667-682.

(25) Ralph, S. A.; Ralph, J.; Landucci, L. NMR Database of Lignin and Cell Wall Model Compounds; US Forest Prod. Lab.: Madison, WI, 2004.

(26) Balakshin, M. Y.; Capanema, E. A.; Chen, C. L.; Gracz, H. S. Elucidation of the structures of residual and dissolved pine kraft lignins 
using an HMQC NMR technique. J. Agric. Food Chem. 2003, 51, 6116-6127.

(27) Balakshin, M. Y.; Capanema, E. A.; Goldfarb, B.; Frampton, J.; Kadla, J. F. NMR studies on Fraser fir Abies fraseri (Pursh) Poir. lignins. Holzforschung 2005, 59, 488-496.

(28) Ibarra, D.; Chavez, M. I.; Rencoret, J.; del Rio, J. C.; Gutierrez, A.; Romero, J.; Camarero, S.; Martinez, M. J.; Jimenez-Barbero, J.; Martinez, A. T. Structural modification of eucalypt pulp lignin in a totally chlorine-free bleaching sequence including a laccase-mediator stage. Holzforschung 2007, 61, 634-646.

(29) Ibarra, D.; Chavez, M. I.; Rencoret, J.; del Río, J. C.; Gutierrez, A.; Romero, J.; Camarero, S.; Martinez, M. J.; Jimenez-Barbero, J.; Martinez, A. T. Lignin modification during Eucalyptus globulus kraft pulping followed by totally chlorine-free bleaching: A two-dimensional nuclear magnetic resonance, Fourier transform infrared, and pyrolysisgas chromatography/mass spectrometry study. J. Agric. Food Chem. 2007, 55, 3477-3490.

(30) Ralph, J.; Marita, J. M.; Ralph, S. A.; Hatfield, R. D.; Lu, F.; Ede, R. M.; Peng, J.; Quideau, S.; Helm, R. F.; Grabber, J. H.; Kim, H.; Jimenez-Monteon, G.; Zhang, Y.; Jung, H.-J. G.; Landucci, L. L.; MacKay, J. J.; Sederoff, R. R.; Chapple, C.; Boudet, A. M. Solutionstate NMR of lignins. In Advances in Lignocellulosics Characterization; Argyropoulos, D. S., Ed.; TAPPI Press: Atlanta, GA, 1999; pp 55-108.

(31) Martinez, A. T.; Rencoret, J.; Marques, G.; Gutierrez, A.; Ibarra, D.; Jimenez-Barbero, J.; del Río, J. C. Monolignol acylation and lignin structure in some nonwoody plants: A 2D NMR study. Phytochemistry 2008, 69, 2831-2843.

(32) Ralph, J.; Landucci, L. L. NMR of Lignins. In Lignin and Lignans; Advances in Chemistry; Heitner, C.; Dimmel, D. R.; Schmidt, J. A., Eds.; CRC Press (Taylor \& Francis Group): Boca Raton, FL, 2010; pp 137-234.

(33) Rolando, C.; Monties, B.; Lapierre, C. Thioacidolysis. In Methods in Lignin Chemistry; Dence, C. W.; Lin, S. Y., Eds. SpringerVerlag: Berlin, 1992; pp 334-349.

(34) Lapierre, C.; Pollet, B.; Monties, B.; Rolando, C. Thioacidolysis of spruce lignin: gas chromatography-mass spectroscopy analysis of the main dimers recovered after Raney nickel desulfurization. Holzforschung 1991, 45, 61-68.

(35) Lapierre, C.; Pollet, B.; Rolando, C. New insights into the molecular architecture of hardwood lignins by chemical degradative methods. Res. Chem. Intermed. 1995, 21, 397-412.

(36) Lu, F.; Ralph, J. DFRC method for lignin analysis. 1. New method for $\beta$-aryl ether cleavage: Lignin model studies. J. Agric. Food Chem. 1997, 45, 4655-4660.

(37) Lu, F.; Ralph, J. Derivatization followed by reductive cleavage (DFRC method), a new method for lignin analysis: protocol for analysis of DFRC monomers. J. Agric. Food Chem. 1997, 45, 25902592.

(38) Lu, F.; Ralph, J. The DFRC method for lignin analysis. 2. Monomers from isolated lignins. J. Agric. Food Chem. 1998, 46, 547552.

(39) Ralph, J.; Lu, F. The DFRC method for lignin analysis. 6. A simple modification for identifying natural acetates on lignins. J. Agric. Food Chem. 1998, 46, 4616-4619.

(40) Tappi. Tappi Test Methods 2004-2005; Tappi Press: Norcross, GA, 2004.

(41) Saito, K.; Fukushima, K. Distribution of lignin interunit bonds in the differentiating xylem of compression and normal woods of Pinus thunbergii. J. Wood Sci. 2005, 51, 246-251.

(42) del Río, J. C.; Rencoret, J.; Marques, G.; Li, J. B.; Gellerstedt, G.; Jimenez-Barbero, J.; Martinez, A. T.; Gutierrez, A. Structural characterization of the lignin from jute (Corchorus capsularis) fibers. J. Agric. Food Chem. 2009, 57, 10271-10281.

(43) del Río, J. C.; Rencoret, J.; Gutiérrez, A.; Nieto, L.; JiménezBarbero, J.; Martínez, Á. T. Structural characterization of guaiacyl-rich lignins in flax (Linum usitatissimum) fibers and shives. J. Agric. Food Chem. 2011, 59, 11088-11099.

(44) Baumberger, S.; Abaecherli, A.; Fasching, M.; Gellerstedt, G.; Gosselink, R.; Hortling, B.; Li, J.; Saake, B.; de Jong, E. Molar mass determination of lignins by size-exclusion chromatography: towards standardisation of the method. Holzforschung 2007, 61, 459-468.

(45) Nakano, J.; Ishizu, A.; Migita, N. Studies on lignin. XXXII. Ester groups of lignin. Tappi 1961, 44, 30-32.

(46) Landucci, L. L.; Deka, G. C.; Roy, D. N. A ${ }^{13}$ C NMR study of milled wood lignins from hybrid Salix clones. Holzforschung 1992, 46, 505-511.

(47) Sun, R. C.; Fang, J. M.; Tomkinson, J. Fractional isolation and structural characterization of lignins from oil palm trunk and empty fruit bunch fibres. J. Wood Chem. Technol. 1999, 19, 335-356.

(48) Meyermans, H.; Morreel, K.; Lapierre, C.; Pollet, B.; De Bruyn, A.; Busson, R.; Herdewijn, P.; Devreese, B.; Van Beeumen, J.; Marita, J. M.; Ralph, J.; Chen, C.; Burggraeve, B.; Van Montagu, M.; Messens, E.; Boerjan, W. Modifications in lignin and accumulation of phenolic glucosides in poplar xylem upon down-regulation of caffeoylcoenzyme A $O$-methyltransferase, an enzyme involved in lignin biosynthesis. J. Biol. Chem. 2000, 275, 36899-36909.

(49) Lu, F.; Ralph, J.; Morreel, K.; Messens, E.; Boerjan, W. Preparation and relevance of a cross-coupling product between sinapyl alcohol and sinapyl p-hydroxybenzoate. Org. Biomol. Chem. 2004, 2, $2888-2890$

(50) Ralph, J. An unusual lignin from kenaf. J. Nat. Prod. 1996, 59, $341-342$.

(51) del Río, J. C.; Marques, G.; Rencoret, J.; Martinez, A. T.; Gutierrez, A. Occurrence of naturally acetylated lignin units. J. Agric. Food Chem. 2007, 55, 5461-5468.

(52) del Río, J. C.; Rencoret, J.; Marques, G.; Gutierrez, A.; Ibarra, D.; Santos, J. I.; Jimenez-Barbero, J.; Zhang, L. M.; Martinez, A. T. Highly acylated (acetylated and/or p-coumaroylated) native lignins from diverse herbaceous plants. J. Agric. Food Chem. 2008, 56, 95259534.

(53) Lu, F.; Ralph, J. Preliminary evidence for sinapyl acetate as a lignin monomer in kenaf. Chem. Commun. 2002, 90-91.

(54) Lu, F.; Ralph, J. Novel tetrahydrofuran structures derived from $\beta-\beta$-coupling reactions involving sinapyl acetate in kenaf lignins. Org. Biomol. Chem. 2008, 6, 3681-3694.

(55) Ralph, J.; Peng, J.; Lu, F. Isochroman structures in lignin: A new $\beta-1$ pathway. Tetrahedron Lett. 1998, 39, 4963-4964.

(56) Zhang, L.; Gellerstedt, G. NMR observation of a new lignin structure, a spiro-dienone. Chem. Commun. 2001, 2744-2745.

(57) Karhunen, P.; Rummakko, P.; Sipilä, J.; Brunow, G.; Kilpeläinen, I. Dibenzodioxocins; a novel type of linkage in softwood lignins. Tetrahedron Lett. 1995, 36, 169-170.

(58) Önnerud, H.; Gellerstedt, G. Inhomogeneities in the chemical structure of hardwood lignins. Holzforschung 2003, 57, 255-265.

(59) Önnerud, H. Lignin structures in normal and compression wood. Evaluation by thioacidolysis using ethanethiol and methanethiol. Holzforschung 2003, 57, 377-384.

(60) Harris, P. J. Diversity in plant cell walls. In Plant Diversity and Evolution: Genotypic and Phenotypic Variation in Higher Plants; Henry, R. J., Ed.; CAB International Publishing: Wallingford, UK, 2005; pp 201-227. 